\title{
Colonial Politics and Women's Rights: Woman Suffrage Campaigns in Bengal, British India in the 1920 s
}

\author{
BARBARA SOUTHARD \\ University of Puerto Rico
}

The historian Geraldine Forbes, writing on the origins of the woman suffrage movement in India, stated: 'the firm insistence of organized women-that they be treated as equals of men on the franchise issue-emerged not from the perceptions of the needs of the women in India, but as the result of the influence of certain British women, in the case of the first demand for the franchise, I 917 , and as a response to the nationalist movement, in the case of the second demand for franchise, 1927-33."'

This quote emphasizes a basic dilemma that plagued the movement for women's rights in India. The campaigns for woman suffrage in India in the early twentieth century were obviously triggered by the example of Great Britain and the work of British women reformers resident in India. The movement therefore was vulnerable to charges that it did not spring from local needs and conditions. Opponents could suggest that the woman suffrage demand was an artificial issue imported from the West that threatened indigenous culture and values. Eventually the woman suffrage movement would have to come to terms with nationalist concerns. Suffragist ideals had to be justified in Indian terms and linked to the nationalist issues of political rights and colonial status which dominated public discourse in the twenties and thirties in India.

The author gratefully acknowledges the financial support of the Smithsonian Institution which provided a grant to cover travel, living, and incidental expenses for research in India, and the Institutional Fund to Promote Research of the University of Puerto Rico.

1 Geraldine Forbes, 'Votes for Women: The Demand for Women's Franchise, 191 7-1937' in Vine Majumdar (ed.), Symbols of Power: Studies in the Political Status of Women in India (Bombay: Allied Publishers, Private, Ltd, 1979), p. 4.

$0026-749 \mathrm{X} / 93 / \$ 5.00+.00 \quad$ (C) 1993 Cambridge University Press 
It is obvious that the colonial situation created difficulties and obstacles for the champions of women's political rights in India which were not present in Great Britain and the United States. The social origins of the movement were not necessarily the same in India as in advanced industrial societies. The nature of the opposition to women's rights was also different in a colonial setting.

This paper aims to explore the social and political dynamics of the suffrage movement in India in the context of a single province. The complex differences in cultural heritage and social organization that characterize linguistic regions of India make it easier to study the factors that created public controversy over women's rights within a single province where one linguistic group dominated. Bengal is an interesting case study because the campaign to get the legislature to pass a bill allowing women to vote was decisively defeated in $192 \mathrm{I}$ and then triumphed in 1925 . The heated debate in 1921 caused considerable surprise because Bengal had been a pioneer in women's education in the nineteenth century and it was generally assumed that the vote would be granted to women with little opposition.

The focus on a single province is also convenient in terms of available data. In 1919, the British decided not to take a decision on woman suffrage on the national level in India. The MontaguChelmsford reforms made woman suffrage a provincial subject which meant that public discussion of political rights for women focused on the debates in the provincial legislative councils. The proceedings of the provincial legislative council, and the coverage of the controversy surrounding the issue of votes for women in the provincial press, are important sources.

In this study we will attempt to define the social origins of the demand for woman suffrage in Bengal. Although it is clear that the activities of British suffragists sparked interest in votes for women, suffrage would not have become an issue in Bengal unless local conditions were receptive. The social composition of the Bengali women's leadership of the suffrage movement will be analyzed. The process of social and economic change in colonial Bengali society must be examined to understand the transformation of women's role that permitted women to participate in the discussion of public affairs in general and the woman suffrage debate in particular.

This article will also tackle the question of why woman suffrage caused such heated controversy in Bengal. The arguments of the supporters and opponents of woman suffrage within and outside the Bengal Legislative Council will be examined. Particular attention will be given to the nationalistic sentiments that were frequently intro- 
duced into the debate, such as concern about the impact of woman suffrage on the national cultural tradition, or the analogies drawn between the politically powerless position of women and the lack of political rights and privileges suffered by men in the colonial system.

Finally, an attempt will be made to identify the political groups that supported or opposed woman suffrage. The votes of the legislature will be analyzed in terms of socioeconomic characteristics, and religious and political party affiliation to find out what lines of cleavage of Bengali society were significant factors influencing attitudes toward political rights for women. The main sources of opposition in 192 I will be identified, as well as the changes that permitted the triumph of woman suffrage in 1925 .

\section{Social Origins of the Woman Suffrage Movement}

Studies of the women's movement on the All-India level in the early twentieth century mention the dominant role of 'middle class' educated women. ${ }^{2}$ The social origins of the educated 'middle class' in India, which was a white collar professional rather than an entrepreneurial elite, were different in each province.

Most members of the English-educated elite in Bengal were drawn from the Hindu upper castes and enjoyed a dominant position on the land and in the urban professions. After British power was firmly established in Bengal, the upper castes benefited from the Permanent Settlement of land revenue, and high percentages of upper caste males learned English and looked for new careers in the British bureaucracy, the new educational institutions and the modern professions. They were not successful in commerce and industry which were generally controlled by other groups. In the late nineteenth century, the stagnation of agriculture and the fragmentaton of holdings created an economic crisis that lowered the standards of living of peasants and proprietors alike. Many upper caste families cut their ties with the land, moved to urban areas, and became largely or exclusively dependent on professional income. ${ }^{3}$

The urbanized professional lifestyle was not limited to the Hindu

${ }^{2}$ For example, see: Geraldine H. Forbes, 'From Purdah to Politics: The Social Feminism of the All-India Women's Organizations' in Hanna Papanek and Gail Minault (eds), Separate Worlds: Studies of Purdah in South Asia (Delhi: Chanakya Publications), p. 219 , and Kumari Jayawardena, Feminism and Nationalism in the Third World (London: Zed Books, Ltd, 1987), p. 99.

3 Anil Seal, The Emergence of Indian Nationalism: Competition and Collaboration in the Later Nineteenth Century (Cambridge: Cambridge University Press, 1968), pp. 45-57. 
upper castes although they had a dominant position in secondary and higher education, government service and the professions. Some Muslim elite families also adopted this style of life, but they were a much smaller group in terms of absolute numbers or percentage of the total Muslim population. Although approximately $5^{\circ}$ per cent of the Bengali speaking population were Muslims, only about 5 per cent of the college population were Muslims. Lower caste Hindus were similarly underrepresented in the colleges and professions. However, many Muslims and lower caste Hindus who managed to enter the modern professions shared the cultural values and lifestyle of the English-educated elite. It should be noted that the social dominance and prestige of this elite, whether Muslim or Hindu, did not necessarily mean economic prosperity. Their very limited involvement in capitalistic enterprise restricted the range of economic opportunities open to them. ${ }^{4}$

In the traditional Bengali upper caste family, women were restricted to the inner compartments of the home and expected to cover their faces in front of men who were not members of the family. Rigid observance of the code of parda was a symbol of high status. Girls married very young and were expected to adapt to the household of their husband's parents and become obedient daughters-in-law. Women were expected to devote themselves to family and religion. Their property rights were very limited and they had almost no access to education. ${ }^{5}$

The changing economic base of the Bengali upper castes that resulted in the consolidation of an urbanized professional elite in the late nineteenth century created new social conditions conducive to the redefinition of the role of women. Professional men seeking upward mobility found that uneducated wives limited by the parda system could not take the lead in the education of their children nor provide wifely support for their professional careers. They admired the British upper middle class pattern in which wives were helpmeets and hostesses who could further their husband's career. Indian intellectuals saw distinct advantages to the social liberty that upper middle class women enjoyed in British society, since the puritanical sexual code of the Victorian age seemed to assure that social liberty would not result in sexual experimentation that would endanger male honor and prestige. ${ }^{6}$

4 Ibid., pp. 57-64.

5 Meredith Borthwick, The Changing Role of Women in Bengal, 1849-1905 (Princeton: Princeton University Press, 1984), pp. 3-25.

6 Ibid., pp. 26-59. 
The Brahmo Samaj, a reformist sect whose membership was largely drawn from the Hindu upper castes, took the lead in advocating reforms to improve the status of women in Bengali society. They favored elementary and higher education for women, widow remarriage, intercaste marriage and participation of women in social and public life. ${ }^{7}$ According to Meredith Borthwick's study of elite Hindu women in Bengal, the Brahmo ideal of female behavior, resisted at first by Hindu conservatives, was widely accepted in upper caste society by the end of the nineteenth century. According to Borthwick, the new stereotype of female behavior 'was created to suit the purpose of an elite under colonial rule, combining the self-sacrificing virtues of the ideal Hindu woman with the Victorian woman's ability to cooperate in the furtherance of her husband's career. ${ }^{8}$

Social changes provided a favorable environment for young people to put into practice some of their liberal ideas about new roles for women. The professional elite was becoming increasingly urbanized which meant less deference to the norms of behavior of conservative rural areas. The search for professional and bureaucratic employment in a very tight job market led young professionals to move away from the extended family. In the early nineteenth century professional men would have left wife and children in the ancestral family home, but it later became customary to move with the nuclear family to the place of employment. Although young married couples always maintained close ties with parents and grandparents, urbanization and increasing geographic mobility gave them more scope to experiment with new concepts of social behavior. ${ }^{9}$

In the late nineteenth century, the Hindu reformer, Vidyasagar, and various members of the Brahmo Samaj took the lead in reformist agitation for women's rights. Widow remarriage was legalized in I 856 , and the custom of child marriage was attacked by the Age of Consent Bill of 1891 prohibiting cohabitation with a wife of less than 12 years. ${ }^{10}$ By 1920 , the attitudes of the Bengali elite toward women had undergone a process of gradual change. Widow remarriage was not commonplace, but it was no longer greeted with the same social opprobrium as previously. Many orthodox Hindu women were no longer observing parda, particularly in urban areas. Many upper caste Hindu parents had come to believe that some education for their

7 Ibid., pp. $49-52$.

8 Ibid., p. 59.

9 lbid., pp. 48-9.

10 David Kopf, The Brahmo Samaj and the Shaping of the Modern Indian Mind (New Jersey: Princeton University Press, 1979), pp. 57, I 26-7. 
daughters was desirable and would enhance rather than destroy their marital prospects. ${ }^{.1}$

The number of girls' elementary and secondary schools in Bengal increased rapidly after 1870 . With the active backing of liberal Brahmos, the Banga Mahila Vidyalay, the first institution to offer women a college curriculum, was founded in 1876 . In 1878 it merged with the Bethune School to become the leading women's higher education institution in Bengal, Bethune College. ${ }^{12}$ Higher education institutions for girls were dominated by Brahmos and Indian Christians in the nineteenth century, orthodox Hindu attendance rose in the first two decades of the twentieth century, while Muslim attendance was not significant until much later. ${ }^{13}$

Educational progress for the masses of girls and women, whether Muslim or Hindu, was very slow. In 1921 , the literacy rate for females was still only approximately 2 per cent. In 1927 , a total of 4 I2,292 girls were attending recognized schools, which represented only 13 per cent of the population of school going age, including 3,727 students in middle and high schools and 384 attending college. While $9^{8}$ per cent of the female population of Bengal remained illiterate in I 92 I, a small elite of highly educated women, dominated by Brahmos, had emerged. ${ }^{14}$

As soon as they gained access to higher education, Bengali women began to play a role in public affairs. In the late nineteenth century small groups of women began joining voluntary associations to work for religious, social and educational reform. Women from Brahmo families, especially the Tagores, took the lead in the nineteenth century. In the eighteen sixties the Brahmo Samaj established a women's association and a women's journal..$^{15}$ Swarnakumari Debi Ghoshal, daughter of the famous Brahmo leader, Debendranath Tagore, started the Sakhi Samiti in 1886 to spread education among women

1 Lakshmi Mitra, Education of Women in India, 192I-1966 (Bombay; MacMillan and Co., Ltd), p. $4^{2}$.

${ }_{12}$ Kopf, The Brahmo Samaj, pp. $3^{8-9}$.

13 Barbara Southard, 'Bengal Women's Education League: Pressure Group and Professional Association', Modern Asian Studies 18, I (1984), pp. 55-88. For statistics see also Mitra, Education of Women in India, pp. 68-9.

${ }^{14}$ Southard, 'Bengal Women's Education League', pp. 57-8, 63-5. Statistics taken from three sources: Mitra, Education of Women in India, pp. $59-67 ;$ S. Nurallah and J. P. Naik, History of Education in India during the British Period (Bombay: MacMillan and Co., Ltd., 1943), p. 28; Mary Fornberg, 'The Education of Women in India in the Nineteenth Century' (unpublished paper, University of Pennsylvania, 1975), pp. 7-17.

15 Borthwick, The Changing Role of Women in Bengal, pp. 273-4. 
and foster their interest in the welfare of the country. This Samiti sponsored a three-day industrial fair demonstrating feminine arts and crafts at the Bethune School to foster a spirit of self-reliance among women. ${ }^{16}$

In the early twentieth century Bengali women began to assume leadership roles in the movements for educational and social reform, which had previously been dominated by male reformers. ${ }^{17}$ Lady Abala Bose, daughter of the Brahmo reformer Durga Mohan Das, became the director of the Brahmo Girls School which was acclaimed as the best girls' school in the province. She founded the Nari Shiksha Samiti (Women's Educational Association) and a widow's home to improve the conditions of women. ${ }^{18}$ In 1913 , Saroj Nalini Dutt, wife of an Indian district officer, began organizing Mahila Samitis in all the areas where her husband was posted. The program of these Samitis included health and hygiene classes, child welfare clinics, arts and crafts, and girls' schools for the uplift of women in the rural areas. ${ }^{19}$

It took slightly more than fifty years from the formation of the first Brahmo women's association to the emergence of a vocal female elite in the nineteen twenties who pioneered organizations on the provincial scale, defined women's issues and organized for political lobbying. The Bangiya Nari Samaj was the first women's association in Bengal consciously to campaign for legislation on women's issues. The association was founded in $192 \mathrm{I}$ to attain the vote for women on the provincial level.

Only a small sector of Bengali women participated in the organized attempt to exert coordinated political pressure to win the vote for women in Bengal. Women leaders obviously believed that they were fighting for measures that would benefit women of all social groups in Bengal, but there is no way of knowing whether their priorities were the same. These women were pioneers in pointing out the patterns of discrimination against women in Bengali society and they were sincere advocates of reforms which they believed would benefit the masses of women who were not in a position to articulate their own demands. During this period the organized women's movement in

${ }^{16}$ Nirmal Sinha, Freedom Movement in Bengal, Who's Who? 1818-1904 (Calcutta: Government of West Bengal Education Department, 1968), pp. 41 7-18.

17 The same tendency for women to become activists in this period prevailed in other parts of India as well. See Forbes, 'From Purdah to Politics', p. 222.

18 Women in India: Who's who? (Bombay: British India Press, 1935), p. 9.

19 G. S. Dutt, A Woman of India: Being the Life of Saroj Nalini Dutt (London: Hogarth Press, I 929), pp. 96-7. See also discussion of Dutt's work in Forbes, 'From Purdah to Politics', pp. 222-3. 
Bengal was a product of social and economic changes that affected the Bengali elite, and the movement inevitably reflected the perspectives and concerns of this social group.

\section{Organization and Social Composition of the Bangiya Nari Samaj}

The campaign for woman suffrage in Bengal emerged in response to the discussion of this issue on the All-India level in conjunction with the Montagu-Chelmsford reforms. The promise of political reforms, made by the British towards the close of the First World War, triggered widespread debate over who should get the franchise. On 20 August 1917 Edwin Montagu, Secretary of State for India, had proclaimed in the House of Commons that the policy of the British Government would be the gradual development of self-governing institutions, with a view to the progressive realization of responsible government in India. Montagu came to India in November 1917 and toured the subcontinent for five months with the Viceroy, Lord Chelmsford, in order to ascertain Indian opinion on specific proposals to be made in the reforms. ${ }^{20}$ Montagu's tour served as a catalyst for long standing political associations to reorganize their forces, and for unorganized political interest groups, such as Indian women, to coalesce and articulate their demands.

A group of prominent Indian women, organized by the Irish feminist Margaret Cousins, requested an audience with Montagu to discuss education and social reform. After receiving a note from Montagu's secretary that only deputations on political subjects would be received, the women decided to broach the question of female suffrage. The delegation included the leading woman educator of Bengal, Lady Abala Bose. ${ }^{21}$

In 1919 , a British Parliamentary Committee recommended that the question of female franchise should be considered a domestic subject, leaving it to the provincial legislatures to decide the matter. All the provincial legislative councils of India passed resolutions extending the vote to women between $192 \mathrm{I}$ and $1929 .{ }^{22}$

In the nineteen-twenties, the focus of the woman suffrage movement had thus shifted from the All-India arena toward a new

${ }^{20}$ J. H. Broomfield, Elite Conflict in a Plural Society: Twentieth Century Bengal (Bombay: Oxford University Press, I968), pp. 98, Iо I.

${ }_{21}$ Forbes, 'Votes for Women', pp. 4-5.

22 Ibid., pp. 6-7. 
emphasis on organization and agitation on the provincial level. The devolution of partial power over education, public health and local government to the provincial legislatures with the implementation of the Montagu-Chelmsford reforms in 1921 created new opportunities for women to seek political support. The reforms created a political system called 'dyarchy' in which the ministers dealing with education, public health and local government were elected by the provincial legislative council, while members of the Executive Council nominated by the British provincial Governor retained control over finance, police, etc. A majority of the seats in the provincial legislatures were filled by elections, but the British government retained the right to fill the rest by nomination. Women reformers who had been discouraged by the cautious attitude of the British government toward social legislation looked with renewed hope to the elected members of the provincial councils.

The idea of introducing a resolution to eliminate the sex disqualification for voting for the Bengal Legislative Council originated among a small group of Brahmo men and women. The prominent Brahmo educator, Lady Abala Bose, had participated in the campaign organized by Margaret Cousins to influence Lord Montagu in favor of female suffrage in 1917 as noted above. It was her husband's nephew, Mr S. M. Bose, moderate nationalist and elected member of the Bengal Legislative Council, who took the initiative to introduce the woman suffrage resolution.

Lady Bose and Mr S. M. Bose were both active members of the Sadharan Brahmo Samaj, the most socially radical of the various branches of this reformist sect. Her father, Durga Mohan Das and his father, Ananda Mohan Bose, were close friends, and were both well known as nationalist leaders and champions of female emancipation in the late nineteenth century. Lady Abala Bose was educated at Bethune College, and married the famous scientist, Sir Jagadish Chandra Bose. She directed the Brahmo Girls School and the Vidyasagar Widows Home and became a member of the executive committee of the Bangiya Nari Samaj. ${ }^{23}$

The Bangiya Nari Samaj (henceforth BNS) was formed at a women's meeting held on 13 August 1921 to support Mr Bose's resolution in favor of suffrage. ${ }^{24}$ Almost all of the leaders of this new lobbying organization were Brahmo women who had been active in

${ }^{23}$ S. M. Bose's mother was Sir J. C. Bose's sister. See Kopf, The Brahmo Samaj, pp. 69-70, 100. For brief biographical details on Lady Abala Bose see Women in India: Who's Who? (1935), p. 9. For details on S. M. Bose see Indian Messenger, 10 Aug. $193^{\circ}$.

24 Statesman, 16 Aug. 1921. 
church work and a variety of social reform organizations. Many were graduates of Bethune College, the pioneer institution for higher education for women in Bengal. Moreover, they tended to come from families that had been associated with the Indian nationalist movement as well as the female emancipation movement in the nineteenth century.

The president of the BNS was Kamini Roy, the renowned poet from a Brahmo family of East Bengal. She was a graduate of Bethune College, who taught at the college level, and worked for various social causes. ${ }^{25}$ The vice president, Mrinalini Sen, was also establishing her reputation as a poet of note. A child widow, who revolted against social taboos and eloped to marry the son of the famous Brahmo leader, Keshab Chandra Sen, she was later to be active in the Bengal Women's Education League, the Bengal Presidency Council of Women and the All-Bengal Women's Union, in addition to representing India at international women's conferences. ${ }^{26}$ The Secretary, Kumudini Bose, graduated from Bethune College and distinguished herself as a poet, journalist and social and political worker. ${ }^{27} \mathrm{Her}$ father was the famous nationalist and social reformer, Krishna Kumar Mitra. ${ }^{28}$ In the twenties, Kumudini not only became prominent in the woman suffrage movement, but she also worked with the Bengal Women's Education League, and the Saroj Nalini Dutt Memorial Association for the uplift of rural women. ${ }^{29}$ She held executive positions in the Brahmo church organization. ${ }^{30}$ In 1932, Mrs Bose ran as an independent candidate for municipal councillor in Calcutta and was elected by a large margin. ${ }^{31}$

Although the top leaders were Brahmos, the BNS attracted the support of women from more conservative communities as well as a few British women. Most of the surnames of the members of the BNS were high caste Hindu, either Brahmo or orthodox. However, several

${ }^{25}$ Padmini Sen Gupta, Pioneer Women of India (Bombay: Thacker and Company, Ltd, 1944), pp. 85-7; Women in India: Who's Who? (1935), p. ix.

${ }^{26}$ Mrinalini Sen, Knocking at the Door (Calcutta: Living Age Press, 1954), pp. i-vi; Women in India: Who's Who? (1935), p. 63. Interview with her daughter, Arati Sen, February 1984 .

${ }^{27}$ Joseph Bagal, 'History of the Bethune School and College, 1849-1949' in Dr Kalidas Nag (ed.), Bethune School and College Centenary Volume, 1849-1949 (Calcutta: Bethune College, 1950), p. 57.

${ }_{28}$ Indian Messenger, 30 March 1924.

${ }^{29}$ Report of the Bengal Women's Education Conference (1928), p. 78; Dutt, $A$ Woman of India, pp. 123-4.

${ }^{30}$ Indian Messenger, 20 March I927.

31 Statesman, 2 April $193^{2}$. 
prominent Muslim women braved the censure of their socially conservative co-religionists to take a strong stand in support of female suffrage. The most famous of these Muslim women was Mrs R. S. Hossein, the founder and superintendent of the most well known Muslim girls school in Bengal, the Sakhawat Memorial Girls' School. ${ }^{32}$

$\mathrm{Mr}$ Bose, the proponent of the woman suffrage resolution in the Bengal Legislative Council, apparently did not anticipate much opposition, because similar resolutions had passed with little difficulty in Madras and Bombay. His supporters in the BNS began to organize lobbying efforts less than a month before the resolution came to a vote on 5 September 1921. Nevertheless, in this short space of time the women launched a vigorous campaign designed to influence educated public opinion in favor of women's rights. No attempt was made to reach the illiterate masses, most of whom were not eligible to vote because of the property qualifications required under the MontaguChelmsford reforms. In I92 I, only approximately ten per cent of the male population and two per cent of the female population of Bengal could read and write, which impeded the growth of mass political campaigns.

The BNS first sought to galvanize their support among the male intellectual elite of Calcutta. On 23 August a large public meeting was held at the Theosophical Society Hall presided over by Professor Manmatha Nath Bose. Prominent politicians and men of letters, such as the nationalist leader, Bipin Pal, and Ramananda Chatterjee, editor of the influential journal, Modern Review, gave supporting speeches, and Kumudini Bose read a letter from the illustrious Rabindranath Tagore. ${ }^{33}$ The BNS also hosted a reception for the press ${ }^{34}$ and lobbied directly with politicians in the Council. Kamini Roy headed a successful delegation that obtained a firm declaration of support from the Minister of Local Government, Sir Surendranath Banerjea, who was also President of the Liberal Party and leader of the moderate faction of the Bengal Legislative Council that favored working with the Montagu-Chelmsford reforms. ${ }^{35}$

The BNS also sponsored two activities designed to garner support from the British community which enjoyed a disproportionately high representation in the Legislative Council. Mrinalini Sen and

32 Syed M. H. Zaidi, The Muslim Womanhood in Revolution (Calcutta: 1937), p. 124.

33 Amrita Bazar Patrika, 24 Aug. 192 I and 21 Sept. 1924 (letters to editor).

${ }^{34}$ Statesman, 28 Aug. 1921 ; Bengalee, 28 Aug. 1921 .

35 Statesman, 27 Aug. I 921. 
Kumudini Bose invaded the exclusive precincts of the Bengal Club to seek support from British legislators. ${ }^{36}$ They also approached and obtained support from the Association of British University Women. ${ }^{37}$

The BNS sponsored many women's meetings in provincial towns. The press referred to women's pro-suffrage meetings at Pabna, Darjeeling, Nilphamari, Raigunj (Dinajpur), Kakina (Rungpur), Chittagong, Bogra, Mymensingh, Kishoregunj, Tangail, and Birbhum. ${ }^{38}$ The network of ladies' associations which the Brahmo Samaj had created in the mufassal served as focal points for the organization of these meetings. In Mymensingh it was the Mahili Samiti organized by Saroj Nalini Dutt, a Brahmo lady who worked for the uplift of rural women, that called for the meeting to support female suffrage. ${ }^{39}$

The BNS position in favor of woman suffrage was expounded in a series of articles by Kumudini Bose published in the journal The Servant. The arguments developed in these articles, later circulated in pamphlet form, were mentioned in the newspapers of the day and were frequently used in the speeches of legislators in favor of suffrage. ${ }^{40}$

Analysis of Mrs Bose's writings shows that she shared the social feminist outlook that was typical in the national women's movement in India during this period. ${ }^{41}$ She sought to broaden Indian concepts of woman's role rather than to mount a direct challenge to tradition. In her writings Mrs Bose did not challenge the traditional concept that the role of women in society differs from that of men, because women are mothers and responsible for the home. However, she did not accept the corollary advanced by conservatives that women are therefore less suited to public life. On the contrary, she maintained that woman's role as guardian of the home should give her special insight and a special interest in public affairs, because there is no aspect of public policy that does not affect the family. According to Mrs Bose, the differences in temperament and social role do not imply lesser intellectual or spiritual ability for women. The contributions of

${ }^{36}$ Sen, Knocking at the Door, p. 150.

${ }^{37}$ Statesman, 30 Aug. 1921.

38 Indian Messenger, 28 Aug. I92 1; Amrita Bazar Patrika, I Sept. I92 I.

39 Amrita Bazar Patrika, 24 Aug. 1921.

40 Statesman, ro Aug. 1921; Amrita Bazar Patrika, I Sept. 1921; Bengal Legislative Proceedings (henceforth $B L C P$ ) vol. IV (I Sept. I92 I), p. $33^{2}$.

${ }^{41}$ See discussion of the social feminism of the All-India women's movement in Forbes, 'From Purdah to Politics', pp. 238-9. For a recent definition of social feminism see Naomi Black, Social Feminism (Ithaca: Cornell University Press, 1989). 
men and women may differ but they are equally valuable and should complement each other in public as well as private life. In particular, she believed that political participation for women would ensure that more attention would be paid to issues such as education and social reform.

\section{Woman Suffrage and the Nationalist Debate in Bengal}

The discussion of the first resolution in favor of woman suffrage, which was introduced in the Bengal Legislative Council on I September $192 \mathrm{I}$, became quite heated on several occasions. The press noted the presence of numerous women in the observer's galleries and their keen interest in the debate. ${ }^{42}$ Many prominent men also attended the debates on votes for women and it was reported that 'feeling was running high in the Bengali community'. ${ }^{43}$ After the first day of discussion there were reports of a possible compromise in the lobby but such rumors proved unfounded because ' . . it was evident very early in the debate that the cleavage of opinion was such that anything in the nature of a patched up settlement was impossible. ${ }^{, 44}$ On the final day of debate the search for compromise gave way to 'brisk canvassing by both parties . . . in the lobby while discussion went on in the hall' ${ }^{45}$ The pro-suffrage resolution was finally defeated by a vote of 56 to $37^{46}$ (6o per cent opposed and $4^{\circ}$ per cent in favor) to the consternation of its supporters who had not anticipated that the measure would generate such heated controversy, much less defeat.

The overconfidence of woman suffrage supporters in $192 \mathrm{I}$ indicates that they did not fully appreciate to what extent the question of women's rights would become enmeshed in the ideological controversies of the nationalist movement and the factional struggles of groups vying to control legislative politics in this era.

The question of the position of women in Indian society had been a sensitive issue since the early nineteenth century. Christian missionaries cited the low position of women in both Hindu and Muslim communities as evidence of the inferiority of both religions and cultures, and held up the position of women in British Christian

\footnotetext{
42 Bengalee, 2 Sept. 192 I.

43 Statesman, 4 Sept. 1921.

44 Statesman, 3 Sept. 1921.

45 Amrita Bazar Patrika, 6 Sept. 1921.

${ }^{46} B L C P$ vol. IV (5 Sept. 192 I), p. 476.
} 
society as a model to emulate. Bengali intellectuals were very much perturbed by this type of critique of their social and religious traditions. Many rejected the missionary insistence that Christianity was the road to modernization and national salvation but they found British social ideals very appealing models. Many early nationalists believed that reform of Indian social and religious institutions must precede movements for national independence. For example, Ram Mohan Roy, the founder of the Brahmo Samaj, advocated the reform of Hinduism and the caste system, the introduction of modern education and improvement of the status of women as positive measures that would regenerate Indian culture and enable her people to develop the capacity to govern themselves in the future. ${ }^{47}$

In the late nineteenth and early twentieth centuries most Brahmos were fervent nationalists who believed that social reform including rights for women would create a progressive society capable of winning political independence. They aligned themselves with moderate factions of the nationalist movement who trusted the British gradually to extend political rights to India, and advocated cooperation with British liberals. They feared that the militant strategy of provoking confrontations with the British might lead to a resurgence of Hindu and Muslim traditional orthodoxy that was more potentially damaging to the cause of individual liberty than the continuance of British rule. ${ }^{48}$

In the late nineteenth century and early twentieth century British resistance to demands for political reform that would have permitted Indians to share in the government of the country sparked the emergence of new militant factions that achieved a dominant position during the 1905 anti-partition agitation. In this period, prominent leaders of the militant or Extremist Party in Bengal demanded immediate independence and moved away from the Brahmo emphasis on social reform toward revivalistic ideologies that stressed the greatness of Indian cultural and religious tradition. ${ }^{49}$ One of the

47 Prabhat Chandra Ganguli, 'Raja Rammohan Roy' in Atulchandra Gupta (ed.), Studies in the Bengal Renaissance (Bengali National Council of Education, 1958), pp. 8-15.

48 Barbara Southard, 'Individualismo y Nacionalismo en la Ideologia de la Sadharan Brahma Samaj' (Individualism and Nationalism in the Ideology of the Sad. haran Brahma Samaj), Estudios de Asia y Africa XVII, I (Jan,-March 1982); Kopf, The Brahmo Samaj, pp. 144-7, 210-14.

40 Barbara Southard, 'Political Strategy of Aurobindo Ghosh: The Utilization of Hindu Religious Symbols and the Problem of Political Mobilization in Bengal', Modem Asian Studies 14, 3 (July t980), pp. 362-7. 
sources of militant political thought was the philosophy of Swami Vivekananda. Vivekananda denounced Brahmo advocacy of social change modeled on British institutions, but he acknowledged the need for reform provided it was compatible with Indian traditions and Indian national pride. He saw the need for liberation of Indian women, but he insisted that they should find their own path consistent with Indian traditions rather than imitate European women. ${ }^{30}$

Militant nationalists who used Hindu symbolism and appeals to traditional culture to buttress their call for immediate independence, rose to prominence in the first wave of intense nationalist protest that swept Bengal in 1905 when the British announced their intention to partition the province. However, their emphasis on a type of revivalism that was most appealing to upper caste Hindus cost them crucial support among the large Muslim population. The legacy of the antipartition agitation was a badly divided nationalist movement. ${ }^{51}$

The announcement of the Montagu-Chelmsford reforms in 1917 , with the promise of an extended franchise and expanded Indian participation in the legislatures, sparked the renewal of struggles between moderate and militant nationalists in Bengal. The Franchise Committee recommended separate electorates and a large number of reserved seats for the Muslim and resident British communities. Bengali militant politicians felt that the concessions made to the British community and separate seats for Muslims would pose the threat of an anti-nationalist front in the legislature. They wrested control of the most important nationalist political association, the Bengal branch of the Indian National Congress, from the moderate Hindu nationalist politicians in 1918. Repressive measures taken by the British government to control nationalist agitation convinced the militants that the reforms were just a ruse to perpetuate British domination. The majority of Congress politicians in Bengal refused to take part in the 1920 elections for the Bengal Legislative Council, and they formally adopted the Gandhian platform of boycott and non-cooperation by the end of the year. Moderate nationalist politicians thus gained control of the Bengal legislature by default. ${ }^{32}$

Most of the leaders of the BNS were moderate nationalists. Obviously, the decision to form an organization to seek the vote from

30 Barbara Southard, 'Vivekananda: The Search for Ethical Values and National Progress under Indigenous Leadership' in J. P. Sharma (ed.), Individuals and Ideas in Modern India (Calcutta: Firma K. L. Mukhopadhyay, 1982), p. 132.

II Broomfield, Elite Confict, pp. 29-34.

32 Ibid., pp. 99-112, 139-41, $65-8$. 
the Bengal Legislative Council implied a willingness to work with the Montagu-Chelmsford reforms. Most of the leaders of the woman suffrage movement in I92 I saw the vote as an instrument to obtain social reforms and expand educational opportunities for women and girls. They believed that devolution of power over local government, public health and education to Indian ministers elected by the provincial legislatures as stipulated by the reforms would create new opportunities for women to influence public policy.

However, some women activists in the non-cooperation movement spoke in favor of the BNS campaign. Sarala Debi Choudhurani who had achieved prominence as an Extremist leader since igo5 warmly supported the woman suffrage campaign ${ }^{53}$ as did Jyotirmoyee Ganguly who led a Women's Volunteer Corps in the non-cooperation movement. ${ }^{54}$ Their position was backed by some male leaders of the non-cooperation movement. Gandhi himself expressed support for the principle of female suffrage, ${ }^{55}$ and B. N. Sasmal, a leading Bengali non-cooperator, came out publicly in favor of the women's demand. However, other male non-cooperators argued that it was tactically incorrect for women to seek the vote in the undemocratic and unrepresentative provincial councils, although they expressed sympathy in principle for woman suffrage. These politicians urged women to join the non-cooperation movement in greater numbers in order to dissolve the legislative councils and force the British to grant truly democratic institutions. ${ }^{56}$

Inside the Bengal Legislative Council, the majority of the politicians were moderates committed to working the MontaguChelmsford reforms. In the 192 I debate on woman suffrage the legislators frequently appealed to nationalist sentiments to support the demand for votes for women. In his opening speech, Mr S. M. Bose argued that granting suffrage to women will enable them to promote female education which is vital to India's progress as a nation. Furthermore, he pointed out that the demand for liberty and democracy sweeping India should logically include political rights for women so that they might contribute fully to the development of their country. ${ }^{57}$ Supporters of Mr Bose in the subsequent debate expanded the argument that votes for women should be a logical extension of the

${ }^{53}$ Manmohan Kaur, Role of Women in the Freedom Movement, 1857-1947 (Delhi: Sterling Publishers Private, Ltd, I968), p. 107.

${ }_{54}$ Statesman, 16 Aug. I921; Amrita Bazar Patrika, 28 Aug. 1921.

55 Indian Messenger, 7 Aug. 1921 .

56 Statesman, 20 Sept. 1921 .

57 BLCP, vol. IV (1 Sept. 1921), pp. 313-17. 
demand for self-government in India, and that women as well as men have a natural right to participate in the public affairs of their country. Mr Surendranath Mullick made an eloquent appeal for support from fellow nationalists for women's political rights when he posed the following rhetorical question:

If we men of Bengal, because we have the power in our hands, refuse to do justice to our own mothers, sisters and wives in the matter of their natural right to representation, then how can we legitimately expect a Government conducted by foreigners, with no racial bond of attachment with us, to surrender to us, a subject race, any of the rights, which we are so earnestly claiming at their hands? $?^{58}$

In addition to pointing out that the rising nationalist movement for democratic reform in India made it an appropriate moment to grant women the vote, supporters of woman suffrage opined that women have special ethical qualities which could purify the political process and promote social reform. Women were pictured as a special interest group who require the vote in order to push social and educational reforms that would not only be of immediate benefit to their own sex, but in the long run would redound to the benefit of Bengali society as a whole. ${ }^{59}$ Political rights for women were thus seen as a positive force that would forward the formation of a progressive and modern society.

The speeches of those opposed to female suffrage did not attempt to counter the nationalist argument that granting the vote to women would be in consonance with the democratic spirit of the times. However, they did not hesitate to attack the contention of female suffrage supporters that the vote is a natural right of both sexes. Many legislators openly maintained the inferiority of woman and pronounced her incapable of judicious participation in public affairs. ${ }^{60}$ The opponents felt that Bengali women could safely rely on their menfolk to defend their interests, ${ }^{61}$ and doubted that there was any widespread desire for the vote among females in the province. ${ }^{62}$ They also deplored the destruction of the parda system of veiling and seclusion of women which they argued would disappear if women began to vote. ${ }^{63}$ One Muslim legislator painted the dismal picture of women

58 BLCP, vol. IV (2 Sept. 1921), p. 375.

${ }^{59} B L C P$, vol. IV (2 Sept. 192 I), p. 395

${ }^{60} B L C P$, vol. IV (5 Sept. 1921 ), p. 449

$61 B L C P$, vol. IV (2 Sept. 1921 ), p. 372

$62 B L C P$, vol. IV (1 Sept. 1921), p. 324

${ }^{63} B L C P$, vol. IV (2 Sept. 1921), p. 371 . 
neglecting husband and children 'even during illness', ${ }^{64}$ as a result of woman suffrage. Another alleged that a woman involved in 'politics and other brainworks' would be unable to breastfeed her children. ${ }^{65}$ Hindu opponents were less inclined openly to defend parda as a desirable social institution, but they joined Muslims in suggesting that female political participation would result in the neglect of home and family, the true sphere of women.

Those who saw woman suffrage as a threat to the traditional social order, raised the so-called 'moral issue' to defeat the suffragists. Kumar Shib Shekhareswar Ray, an aristocratic Hindu, begn by alleging that prostitutes, who were free of the constraints of parda that limited the mobility of respectable women, would flock to the polls. ${ }^{66}$ Subsequent speakers repeatedly returned to this argument in an obvious attempt to use an emotional issue to turn the tide against suffrage. On the final day of the debate a note was placed on each legislator's desk warning about the danger of prostitutes voting. ${ }^{67} \mathrm{It}$ was difficult for proponents of woman suffrage to counter such allegations, without appearing to give too much weight to a frivolous argument. The BNS publicized a letter from Margaret Cousins that expressed their sense of frustration with the course of the debate in the Bengal Legislative Council:

I was present at the woman suffrage debates in both Madras and Bombay Councils, and I was shamed and shocked by the low tone of the Bengal Council debate-when compared with these others. With a few striking exceptions the speeches were a display of lack of faith in womankind, determined arbitrary restrictions of her sphere of influence or interests, inflated exaggerations of simple facts into absurd fictions, and a horrid harping on the possibility of women of ill-fame voting which reflected more on the contents of the minds of the Bengal Councillors than anything else. ${ }^{68}$

The members of the Bengal Legislative Council who favored woman suffrage believed that the granting of a higher status and the creation of new opportunities for women was an integral part of the modernizing process that must go forward if India was to achieve national independence and a respectable place among nations. The opponents saw woman suffrage as a threat to traditional values that would undermine cultural identity.

\footnotetext{
${ }^{64} B L C P$, vol. IV (5 Sept. Ig2 I), p. 450.

$65 B L C P$, vol. IV (5 Sept. Ig2 I), p. 470.

${ }^{66} B L C P$, vol. IV (1 Sept. Ig2 I), pp. 324-5.

67 Amrita Bazar Patrika, 6 Sept. 1921.

${ }^{68}$ Statesman, 9 Sept. I92 I.
} 
A resolution in favor of suffrage was introduced for the second time in the Bengal Legislative Council in August 1925. During the intervening four years, the political situation in Bengal and the composition of the Council had changed dramatically.

In 1922 the leading militant politician in Bengal, Chittaranjan Das advocated a change in non-cooperation policy. After Gandhi called off the economic boycott and other non-cooperation activities in 1922, Das joined other Congress politicians who proposed to contest the next elections, win majorities in the legislatures, and carry out a policy of non-cooperation from within the Government. When the dissidents failed to overcome Gandhian opposition to their platform in the annual meeting of the Indian National Congress in December 1922, they formed the separate Swaraj Party to contest the I923 elections. $^{69}$

In Bengal, Chittaranjan Das's base of support was the militant nationalists of the Bengali upper castes, but unlike the Hindu militants during the 1905 anti-partition agitation he consciously and successfully sought Muslim support. Discussions with leading Muslim politicians created a Hindu-Muslim alliance on the basis of Swarajist support for separate communal electorates for Muslims, preference for Muslims in recruiting for the civil service until they reached parity with Hindus, and no Hindu interference with cow killing. The Swarajist platform of communal harmony and the demand for immediate self-government led to their triumph in the November 1923 elections for the Bengal Legislative Council. They won a majority of elected seats but not an absolute majority, because there were many appointive seats filled by nomination by the British Government. $^{70}$

Upon the death of Chittaranjan Das in I925, the leadership of the Swaraj Party in Bengal passed to J. M. Sen Gupta. ${ }^{71}$ The new leader found it increasingly difficult to hold together a united coalition of Hindu and Muslim Swarajists. ${ }^{72}$ J. M. Sen Gupta was personally a strong supporter of measures to improve the conditions of women and his wife, Nellie Sen Gupta, an English woman, was active in the Indian women's movement. Nevertheless, Sen Gupta decided not to impose party discipline in favor of woman suffrage, undoubtedly

${ }^{69}$ Broomfield, Elite Confict, pp. 227-35; Leonard Gordon, Bengal: The Nationalist Movement: 1876-1940 (New York: Columbia University Press, 1974), pp. 20 I-I I.

${ }^{70}$ Broomfield, Elite Conflict, pp. 238-47. Gordon, Bengal, pp. 20 I-I I.

71 Broomfield, Elite Confict, p. 268.

72 Statesman, 14, 19, and 20 Aug. 1925 
because he thought it would be too costly to risk antagonizing Muslim members of his party who were socially conservative.

The atmosphere of the 1925 debate on woman suffrage was more decorous than in $192 \mathrm{I}$. In this second round of debate those opposed to female suffrage were less vociferous and they did not dwell on the supposedly inherent inferiority of women as in the first debate. Only one legislator mentioned the possibility that prostitutes might vote. ${ }^{73}$ In 1925, very few Muslims and no Hindus openly defended parda as a desirable social custom that would be threatened by extending political rights to women, nor did they frequently express the narrow view that women should be confined to the home. ${ }^{74}$ Opponents of woman suffrage seemed to feel that the tide of opinion in the Council was against them.

In general, the arguments advanced for and against woman suffrage in 1925 were updated versions of those advanced in 1921 . Supporters of female suffrage in $192 \mathrm{I}$ had referred to the implementation of the Montagu-Chelmsford reforms, which extended partial selfgovernment to the provinces of India, as an appropriate time to extend democratic rights to women. In 1925, several members of the Swaraj Party said that in the midst of their party's drive for complete self-government it would be appropriate to include women in the march toward democracy by giving them the vote.

Nirmal Chandra Chunder, a Swarajist representing a non-Muslim Calcutta constituency, said that it would be illogical to ask women to serve their country and at the same time deny them the political rights which would enable them to do so. ${ }^{75}$ Hemanta Kumar Sarkar, a maverick politician who was in and out of the Swaraj Party, expressed similar sentiments and deplored the fact that woman suffrage was not made a matter of party discipline. Sarkar, in a humorous vein, said that it would be illogical for those who want Home Rule to deny the franchise to the rulers of their homes. In a more serious tone, he then urged fellow Swarajists as individuals to take a stand on women's rights consistent with their democratic principles. ${ }^{76}$

In the debate over suffrage neither Hindu nor Muslim Swarajists demonstrated a revivalistic tendency to defend traditional customs in order to justify their opposition to British rule. Swarajists spoke of women's rights as a universal concept fundamental to the develop-

${ }^{73} B L C P$, vol. XVIII (19 Aug. 1925), pp. 29 I-2.

${ }^{74}$ For one exception see ibid., pp. 305-6.

75 Ibid., pp. 304-5.

76 Ibid., p. 293. 
ment of a modern democratic polity. They demonstrated no particular attachment to traditional concepts of the family and the role of women as compared to other political groups in the legislature. Thus, Hindu Swarajists avoided perpetuating the old link between religious revivalism and militant nationalism that had so limited the 1905 revolutionary movement.

At times it seemed that the main issue of debate in 1925 was whether the Swaraj Party was sincere in its advocacy of democracy, rather than whether women should vote. The main target of disparaging remarks was the alleged inconsistency of the Swaraj Party rather than the incompetence of women which had been frequently remarked in 1921. Supporters of the British Government quickly picked up Sarkar's argument that the Swaraj Party should have declared itself in favor of voting in block for woman suffrage if they were really sincere in advocating democratic reforms. Such critics ignored the fact that the Government and other political groups had also taken an officially neutral stance on the question of woman suffrage. ${ }^{77}$

One of the most potent arguments against woman suffrage advanced in both the $192 \mathrm{I}$ and 1925 debates was the suggestion that the vote would benefit only a small number of women. In I 92 I certain legislators pointed out that Brahmo, Indian Christian and British women would be the most likely to go to the polls. ${ }^{78}$ These opponents of woman suffrage duly noted the low participation of women in prosuffrage rallies.

The Montagu-Chelmsford reforms had included communal electorates, (separate electorates for Muslims) and reserved seats for British officials and nominated members representing specific religious and economic interest groups, such as untouchables and Indian Christians. The way the seats were distributed in the legislature created an atmosphere in which legislators were constantly calculating the probable impact of any measure on the voting strength of their religious community or interest group. This preoccupation with the rights, political benefits and privileges that each religious community would enjoy relative to others was called communalism. Muslims later rejected the term as they began to articulate a position of separatist nationalism.

Several Muslim legislators addressed themselves to the issue of whether female suffrage might have a negative impact on Muslim

77 Ibid., pp. 297-8, 302 .

${ }^{78} B L C P$, vol. IV (2 Sept. 192 I), pp. $37^{8-80}$ and (5 Sept. 1921), p. 466. 
representation in the legislature. The assumption underlying most of these speeches seems to have been that Muslim women, who were less educated and more strictly confined by the parda system, would be less likely to vote than women of other communities. One Muslim proponent of suffrage questioned this assumption by pointing out that more Muslim women might be eligible to vote because liberal inheritance rights permit Muslim women to acquire more property than their Hindu sisters. ${ }^{79}$ However, the general consensus was that the force of parda and educational handicaps would ensure that Muslim women were the least likely to vote. In 192 I, A. K. Fazlul Huq, who favored female suffrage, tried to persuade his co-religionists that there was really no reason to fear that Muslim representation would be affected by female suffrage. According to Huq:

It has been said that if the Franchise is given to ladies, Moslem interests will, in a mysterious way be affected. . . . I cannot understand how ... the proportion of seats is fixed by statute. If, at any time, Hindu seats are increased, Moslems will have $4^{\circ}$ per cent of the non-Muhammedan Indian seats - then where is the danger? ${ }^{80}$

The reassuring tone of Huq's speech only serves to emphasize the fear of Muslim delegates that female suffrage would weaken Muslim voting strength. No one rose in I 92 I to counter Huq's argument, but it is probable that concern over future Muslim voting strength influenced legislators against votes for women. When the question of woman suffrage was again debated in 1925 , Nurul Huq Choudhury pointed out that the predictably lower participation of Muslim women as compared to women of other communities might lower the overall percentage of Muslims going to the polls in comparison to Hindus. Choudhury acknowledged that Muslim representation was at present protected by a proportionate number of separate seats, but he pointed out that at some future date the lowering of the voting rate among Muslims could provide ammunition for those who wish to reduce the quota of Muslim seats in the legislature. He, therefore, opposed granting the vote to women. ${ }^{81}$ 


\section{Analysis of the Votes on Woman Suffrage}

In 1921 , the resolution to eliminate the sex disqualification for the provincial electoral rolls in Bengal was defeated by the substantial majority of $5^{6}$ to 37 (see Appendix, Tables A-I and A-2) or 6o per cent opposed and 40 per cent in favor. Mrs Mrinalini Sen, vicepresident of the BNS, analyzed this humiliating defeat in the following terms: ' . . . most of the Moslem members under the guidance of the Moslem minister and practically all the British official and non-official members and three or four Hindu Landholders who habitually always vote on the official side voted against it in a bulk. . . ${ }^{82}$

Mrs Sen's observations with regard to the solid opposition of Muslims and nominated British officials are completely accurate. Her conclusion about the opposition of most Hindu landholders to female suffrage is substantially correct, though it is not quite accurate to categorize them all as consistent government supporters. Her comments about British non-officials in the legislature are not borne out by the voting record.

It can be noted that Mrs Sen did not analyze the vote in terms of political parties or geographic distribution. Since the real opposition to the British Government, the non-cooperator wing of the Congress Party, was not present in the I92 I legislature, the political situation in the Council was nebulous; no clear-cut parties with consistent ideological positions emerged. Attempts to analyze the voting in I 921 on woman suffrage in terms of political attitudes toward the British Government (dividing the legislators into three groups: those who fairly consistently supported resolutions sponsored by the British Government, those almost always opposed, and those with a mixed record) did not yield any significant correlation. Nor was there any significant difference in the voting pattern of legislators representing rural versus urban constituencies. Contemporary analysts, like Mrs Sen, were apparently correct in emphasizing religious, ethnic and socio-economic cleavages as the determining factors influencing the voting pattern in the Bengal Legislative Council on woman suffrage in I 921 .

If we analyze votes on female suffrage in terms of religious affiliations, Muslim legislators were clearly the core of the opposition. Of the 35 Muslims who voted, 27 were opposed and 8 were in favor, i.e.

${ }^{82}$ Sen, Knocking at the Door, p. I 45. 
77 per cent rejected votes for women (see Tables A-I and A-2). This solid Muslim opposition, which was noted by the press, ${ }^{83}$ no doubt stemmed from a combination of factors. The debate revealed that Muslims were much more likely than members of other religious groups openly to support parda and restriction of women to the home. The traditional prejudices against women in public affairs were heightened by concern that Muslim women would be less likely to vote than other women, and their limited electoral participation could undermine the future voting strength of the Muslim community.

In contrast to overwhelmingly Muslim opposition to female suffrage, Hindu legislators were almost evenly divided. Of the $44 \mathrm{Hindu}$ legislators both elected and nominated who voted on this issue, 23 voted against and $2 \mathrm{I}$ voted in favor of extending the vote to women (see Table A-I and A-2). If we eliminate the two nominated Marwari legislators, Babu Chaneshyandas Birla and Babu Keshoran Poddary, who represented a very socially conservative non-Bengali business community, the rest of the Hindus were evenly divided.

Mrs Sen's comment about Hindu landlord opposition to female suffrage, quoted above, referred to the well known social conservatism of the old landed aristocracy in Bengal, as well as their historical tendency to support the British. If we analyze the votes of the 13 Hindu legislators who were elected representatives of landholders' constituencies, titled aristocrats, or who were referred to as big landholders in the course of the 1921 legislative debates, it is evident that this group was largely opposed to female suffrage. Ten out of fifteen, or 67 per cent, voted against (see Table A-3).

The role of zamindars and title holders, both Hindu and Muslim, in defeating the suffrage resolution and their presumed tendency to support the British official line, was denounced in protest meetings and by the press. A speaker at a suffragist meeting called to protest the vote denounced the opposition of zamindars, and suggested that the lopsided voting strength of this class in the reformed councils was an obstacle to reforms desired by the middle class. ${ }^{84}$ One journalist remarked derisively that only three of the many titled members of the Bengal Legislative Council had voted for the resolution while all other 'Rajas, Maharajas, Maharadhirajas, Bahadurs, Nawabs, Nawab Bahadurs, Rai Sahibs and Khan Bahadurs and Khan Sahibs voted solidly against the motion.' ${ }^{85}$

${ }^{83}$ Statesman, 7 Sept. 1921.

${ }^{84}$ Statesman, 14 Sept. 1921 .

85 Statesman, I I Sept. I 92 I. 
Of the 44 Hindu legislators, two were Marwaris, 15 were identifiable as titled aristocrats or large landholders, and three were clearly identified with the lower castes. Judging from the surnames of the remaining 24 Hindu legislators, they were almost certainly drawn from the so-called Bengali Hindu middle class of professional men, small landholders and rentiers of the upper castes who dominated elections for non-specialized constituencies in this era. Fifteen of these men (63 per cent) favored votes for women and nine were opposed (see Table A-3). These figures support the widely accepted thesis that this segment of Hindu society had accepted more liberal views of the role of women by 1920 . The restrictions of parda were weakening and female education was widely accepted among educated Hindus of the upper castes.

Although the two representatives of the Hindu scheduled castes voted against female suffrage it is impossible to deduce valid conclusions from this small sample of non-elected nominated legislators about the attitudes of the lower castes toward women's role or reforms affecting women.

The Anglo-Indian and Indian Christian representatives in the Legislative Council, as well as the elected British representatives all made strong statements in favor of female suffrage and voted accordingly ${ }^{86}$ Education was widespread among women of these communities and they had been active in social work and war work. Moreover, these three communities viewed themselves as socially progressive in comparison to Hindus and Muslims, whose views on women they disparaged. They were also disposed to follow the lead of Great Britain where women had already gained the vote.

In contrast to the solid support of British elected members, 6 out of 7 of the nominated British officials, who voted in the legislature, rejected woman suffrage (see Table A-4). The British Government had taken an officially neutral stance on the issue. However, the overwhelmingly negative vote of the British must have reflected an unannounced Government policy, because it is unlikely that their social attitudes could have differed so sharply from those of their countrymen who represented private interests in the legislature. The pro-British press expressed surprise that British officials had voted against suffrage. The BNS publicized a letter from Margaret Cousins that pointed out that the British had taken an official position that woman suffrage was a question for Indians to decide. In spite of their

${ }^{86} B L C P$, vol. IV (2 Sept. 192 I), pp. 393-4 and vol. IV (2 Sept. 192 I), pp. $3^{88-9 .}$ 
commitment to remain neutral, British members of the Bengal Legislature campaigned against the reform. According to Mrs Cousins: 'This is not playing the game, and it is a procedure that was not followed in other Presidencies where even when they spoke on the subject they refrained from voting. ${ }^{, 87}$

It is probable that British officials took a different stance on the woman suffrage resolution in Bengal because they perceived their political position in this province as less secure than elsewhere in India. The British in Bengal, who had been faced with militant opposition from the Hindu educated elite for two decades, reacted with dismay to the announcement of the Montagu-Chelmsford reforms in 1917. Since it was not possible to block the promised reforms, they developed a successful strategy of protecting British interests in Bengal by demanding an increase in the number of nominated members of the legislature to be created. Once the reforms were implemented, British officials sought to cement alliances with key groups as a counterweight to the vociferous demands of the Hindu educated elite. ${ }^{88}$ Muslims, large landholders and titled aristocrats, who held conservative social views, were well represented in the 1921 legislature in Bengal. British officials were undoubtedly anxious to avoid offending the religious and social sensibilities of these groups, whose support they would need in future votes on issues that might be crucial to the continuation of British power.

In 1925 the vote in the Bengal Legislative Council on woman suffrage was an almost exact reversal of the previous voting percentages. In $19^{2} 5$, the resolution was approved by 59 per cent ( 54 out of 92) in contrast to 6o per cent against in 192 I (see Table B-I).

In this brief period of four years the composition of the Bengal Legislative Council had changed substantially in response to rapid changes in the political scene. Of the 92 representatives voting on the question of female suffrage in 1925 , only 17 ( 18 per cent) had voted on the resolution four years before, while a total of 75 ( 82 per cent) were new men. The reversal of the vote on woman suffrage was due to a more positive attitude toward women's rights among new legislators rather than any change of heart among holdovers from the 1921 Council. Of the 17 Council members who voted on both resolutions for female suffrage, i 6 were consistent (see Table B-2).

In I92 I, political alignments in the Council were constantly in flux because the legislature was not clearly divided into parties. However,

${ }^{87}$ Statesman, 9 Sept. 1921.

${ }^{88}$ Broomfield, Elite Conflict, p. I 10. 
after the election of 1923 a clearly defined opposition party, the Swarajists, entered the Council and voted consistently against the official British Government position. The party discipline displayed by the Swarajists makes it easy to identify them by their voting records. Analysis of the 1925 vote on woman suffrage can thus take into account party affiliations as well as the socio-economic characteristics and the religious and ethnic affiliations of the legislators who voted.

By the time the Swarajists entered the Council in I924, they had been reintegrated into the Congress Party as the dominant element. They were non-cooperators who believed that it would be more effective to oppose the British from within the Bengal Legislative Council than from outside. They wished to use the legislature as a forum to demonstrate that the Montagu-Chelmsford reforms were unworkable. They hoped to bring about the rapid collapse of the dyarchy system, that divided power between British officials and partially elected legislatures, through a policy of obstruction in the legislatures. The Swarajists won many important votes in the legislature in the course of 1924 and 1925 , but their strategy did not lead to rapid progress toward self-government which was their goal. For example, in August 1925 the Swarajists won votes to refuse to pay the proGovernment ministers' salaries. The ministers resigned and the British suspended the Montagu-Chelmsford constitution in the province until they were convinced that the political situation was sufficiently favorable to reconvene the legislature. Since they had the option of ruling by decree and stepping up repressive measures against the nationalist opposition, they were not immediately forced to grant further reforms in the direction of self-government. ${ }^{89}$

The Swarajists had won a large majority of the general constituency (in effect Hindu) seats in the 1923 elections and approximately half of the Muslim seats. However, a substantial number of seats were filled by members nominated by the British Government or elected by special interest groups, such as European trade and commerce, landholders, etc., who generally supported the British. Although the Swarajists had a majority of the Hindu and Muslim seats, they did not enjoy an absolute majority in the legislature. The Swarajists were opposed by a pro-British Government party. There were also intermediate groupings who sometimes voted with the Swarajists (particularly on issues of civil rights) and at other times supported the British line. The Swarajists needed support from other groups to win key

89 Ibid., pp. 244-59. 
votes and they were most likely to get votes from non-Swarajists who were nevertheless members of the Congress Party and from unaffiliated Muslims. ${ }^{90}$

For the sake of simplicity in the analysis of voting on woman suffrage, all legislators who did not consistently follow the Swarajist party line will be considered non-Swarajists. It should be noted that neither the Swarajists nor any other political grouping called for party discipline on the question of woman suffrage. In the atmosphere of intense struggle between pro and anti-Government groups no one wanted to risk alienating socially conservative members whose support they needed on other issues considered more crucial to the political future.

If we first analyze the vote in terms of ethnic and religious divisions, it is obvious that the Muslim representatives continued to constitute the core of the opposition to female suffrage. The British were evenly divided, and Hindus and Anglo-Indians were in favor. The AngloIndians voted roo per cent in favor, 72 per cent of the Hindu legislators approved the resolution and only 50 per cent of the British representatives and 39 per cent of the Muslims voted in favor.

The two Anglo-Indian representatives, $\mathrm{Dr} \mathrm{H}$. W. B. Moreno, who moved the suffrage resolution, and $\mathrm{Mr} \mathrm{H}$. Barton, made eloquent speeches in favor of votes for women, and voted accordingly (see Table B-I). In contrast to the unanimous support of the AngloIndians, the British members of the Council were divided, six in favor and four against. As in $192 \mathrm{I}$, it may be noted that nominated officials were less likely to support woman suffrage than elected members. In I 925 four out of eight nominated officials were opposed. On the other hand, the two elected British representatives spoke strongly in favor of woman suffrage (see Table B-3). It appears that public opinion among British residents in Bengal favored votes for women, but British officials in the Bengal Government continued to harbor political doubts about the wisdom of this reform.

In I925, Muslim representatives were not so overwhelmingly opposed to votes for women as they had been in 1921 . In 1925,20 of 33 Muslims voted against the resolution (6r per cent) as compared to 77 per cent opposition in 1921 . There is no indication that Muslims representing rural constituencies were more or less opposed to female suffrage than their urban counterparts. However, if we analyze the votes of titled Muslim aritocrats, they were even more strongly opposed than other Muslim legislators in the 1925 Council, voting 3 to I against the resolution (see Table B-4).

90 Ibid., pp. 244-7. Gordon, Bengal, pp. 207-I I. 
The most significant factor affecting the Muslim vote on female suffrage in 1925 was party affiliation. Those who voted consistently with the Swarajist Party voted heavily in favor of votes for women, although the party had not instructed its members on how to vote on this issue. All other Muslims in the Council voted overwhelmingly against. Of the 12 Muslims voting consistently Swarajist, 8 favored the franchise for women and 4 were opposed (67 per cent in favor and 33 per cent opposed). Of the 2 I non-Swarajist Muslims who voted on this resolution 5 supported it and 16 were opposed (24 per cent in favor and 76 per cent against). Thus, if we subtract Muslim Swarajist votes, other Muslim representatives were as solidly opposed to woman suffrage in $19^{2} 5$ as the legislators of this community had been in I $^{2} \mathrm{I}$ (see Table B-4).

The more liberal attitude of Muslim Swarajists toward women's rights may be explained in terms of the ideological atmosphere of the movement and the Swarajist quest to downplay communal tensions. The Swarajist legislators were a highly motivated and disciplined political group who shared dedication to a political ideal. Although some cracks had appeared in the Swarajist alliance by August 1925, those who had stuck with the party still considered their cause worth sacrificing for. Muslim Swarajists in particular had repeatedly rejected British blandishments to abandon the Swarajist cause. It is quite conceivable that their devotion to a radical cause, which implied a clean break with traditional collaborationist politics, could have infected Muslim Swarajists with enthusiasm for re-evaluation of traditional modes of thinking on questions of social change as well.

For most Muslim Swarajists, joining the party meant suppressing the tendency to consider every issue solely in terms of its impact on the political strength of their community. Of course, it is also true that some Muslim Swarajists had joined the party because they believed an alliance with the Hindus would benefit their community more than the continuance of the alliance with the British, and several Swarajists, like Nurul Huq Choudhury continued to speak in a communalist tone. However, Muslim Swarajists as a whole seem to have been reassured by their alliance with Hindus that Muslim interests would be taken into account. Therefore, they were less likely than other Muslim representatives to have been affected by the argument that woman's suffrage would damage Muslim political power because a smaller percentage of Muslim than Hindu women would go to the polls.

Of the 47 Hindus in the Council who voted on the question of female suffrage in 1925, 34 supported the resolution and i 3 were 
opposed (72 per cent in favor and 28 per cent opposed). This represents a significant change in the climate of opinion among Hindus, since the representatives of this community were almost evenly divided on the question of female suffrage in $192 \mathrm{I}$. There was no marked difference in the voting pattern of Hindus representing rural and urban constituencies. As had been the case in $192 \mathrm{I}$, members of the old Hindu aristocracy, large landholders and titled aristocrats, voted more conservatively than their co-religionists from middle social strata. Among 8 identifiable Hindu aristocrats, 5 voted against female suffrage in 1925 . There was also an identifiable group in the Council who regarded themselves as spokesmen for the underprivileged, namely the laboring classes, lower castes and tenant farmers. All of them voted in favor of woman suffrage (see Table B-5).

If we analyze the Hindu vote in terms of party affiliations, it may be observed that the Swarajist Hindus voted more heavily in favor than those of any other political group. However, the difference between Swarajist and non-Swarajist Hindus is not as dramatic as in the case of Muslims. Seventeen Swarajists voted in favor of female suffrage and four were opposed ( $8 \mathrm{I}$ per cent in favor and ig per cent against). Among non-Swarajists, seventeen supported the resolution and nine were opposed ( 65 per cent in favor and 35 per cent opposed as shown in Table B-5).

The emergence of a broadbased Hindu majority in favor of woman suffrage indicates a change of public opinion in this community. The Hindu swing toward women's rights cut across party lines and included all social classes except the old style aristocrats. This change in public opinion could occur because Brahmo ideals advanced in the nineteenth century were gradually becoming generalized among the Hindu elite in the twentieth century.

The higher percentage of Swarajists than non-Swarajists who favored female suffrage shows that the majority of Swarajists, whether Hindu or Muslim, took to heart the chidings of their opponents who admonished them to demonstrate consistency in their democratic ideals by extending them to women.

\section{Conclusion}

The woman suffrage movement in Bengal was nurtured in an environment of social change that opened up new possibilities for women of the elite. The inspiration for campaigns for votes for women in the various provinces of India was imparted by British suffragists, as 
Geraldine Forbes and other historians have noted. Nevertheless, the enthusiastic support that a sector of Bengali women demonstrated for the cause of women's political rights reflected their own needs and aspirations.

The studies of various historians have shown that the rise and consolidation of an English-educated professional elite in Bengal, that performed important functions in the British colonial system, had significant repercussions for the status of women. Meredith Borthwick has suggested that the first impulse for change came from men who wanted educated wives who could serve as helpmeets in their careers and guide their children toward academic success and social mobility. Reformist movements arose in the nineteenth century that opposed seclusion of women and favored access to education. Many elite women took to education with enthusiasm and those who acquired education took advantage of opportunities to participate in social and religious reform associations outside the home.

The woman suffrage movement was one of the first political campaigns spearheaded by women's associations in Bengal. The leadership of the BNS, the association that organized campaigns in 1921 and 1925, was composed of highly educated women, many of whom were educators or active participants in social service or reform associations. Although orthodox Hindu and Muslim women were involved in the BNS, most of the top leaders were members of the Brahmo Samaj, a reformist sect whose membership was largely drawn from the Hindu upper castes. Most BNS leaders were fervent but moderate nationalists who believed it was advisable to work with the Montagu-Chelmsford reforms.

The BNS leadership saw the demand for votes for women as a strategy to win a hearing for the social reform causes they espoused and to expand the public role they had already begun to carve out for themselves by I 920 . Woman suffrage was thus not seen as an isolated political issue, but as a tool to promote educational reform and social legislation favorable to women.

The woman suffrage campaign was a movement confined to the elite that did not touch the masses of illiterate women in Bengal. Suffrage for men was limited by property and educational qualifications under the Montagu-Chelmsford reforms, so the issue was gaining access to the decision-making process for educated women. Women leaders saw themselves as guardians of the interests of poor women, but in the twenties they had not as yet developed effective strategies to communicate with or mobilize the masses of women.

Forbes has shown that the linking of woman suffrage to issues of the 
nationalist movement on the All-India level ensured the implementation of the reform in the 1935 constitution. The present study of the process of passing of provincial legislation in favor of woman suffrage in Bengal in the twenties confirms the hypothesis that suffrage leaders were able to win votes for women in India without mobilizing mass support because they successfully linked their cause to nationalist issues. Public discourse in Bengal as well as elsewhere in India was dominated by the nationalist debate. In order to gain acceptance for their cause, advocates of woman suffrage stressed the compatibility of the petition for votes for women with the demand that the colonial power grant political rights to all Indians. They argued that the concepts of democracy and self-determination that justified the demand for independence for India should also guarantee the rights of all citizens.

Suffragists avoided polemical arguments that might have aroused nationalist concern about jettisoning aspects of Indian traditional culture that were still highly valued. They proposed to expand and modernize the role of women while preserving the traditional emphasis on the special mission of women as mothers and caretakers of the family and home. Suffragists argued that women should expand their role to enter public life so that their knowledge of the problems and needs of the family and their concern for the weak and disadvantaged could influence public policy in the direction of much needed reforms.

In spite of the skillful integration of the woman suffrage issue into the prevailing nationalist debate, the first resolution in favor of votes for women was defeated by a large margin in the Bengal Legislative Council in $192 \mathrm{I}$. The appeal to nationalist sentiments did not ensure immediate victory because the nationalist movement was more deeply divided in Bengal than in other provinces in this period.

In the atmosphere of rivalry of Muslim and Hindu interests that prevailed in the Bengal Legislative Council, it was inevitable that many legislators would weigh to what extent their own community's political representation would be affected by granting votes to women. Muslim preoccupations about whether as many Muslim as Hindu women would go to the polls undoubtedly bolstered their conservative social view that women should stay home. The British looked to Muslims and Hindu aristocrats as allies against the insistent political demands of the Hindu professional elite. British officials abandoned their commitment to take a neutral stance to vote against woman suffrage as a gesture of solidarity with their political allies.

The situation changed dramatically in 1925 when the Swarajists, 
members of a militant nationalist party with a non-communalist ideology, assumed a dominant role in the legislature. There was a temporary lull in communal tensions when the Swarajist party achieved an alliance of Hindus and Muslims in favor of immediate independence. High percentages of Hindu and Muslim Swarajists voted in favor of votes for women which ensured a decisive victory for suffrage. Under these changed circumstances it was possible for the woman suffrage resolution to ride to victory on a wave of nationalist enthusiasm.

\section{Appendix}

TABLE A-I

${ }_{5} 6$ Legislators who Voted Against Female Suffrage in 1921 by Religious Affliation and Constituency

\begin{tabular}{|c|c|c|}
\hline Name & Religion & Constituency \\
\hline Addy, Babu Amulya Dhone & $\mathrm{H}$ & $\begin{array}{l}\text { Bengal National Chamber of } \\
\text { Commerce }\end{array}$ \\
\hline \multicolumn{3}{|l|}{ Afzal, Nawabzadá K. M. Khan } \\
\hline Bahadur & $\mathbf{M}$ & Dacca City (M) \\
\hline Ahmed, Khan Bahadur Maulvi & & \\
\hline Wasimuddin & $\mathbf{M}$ & Pabna (M) \\
\hline Ahmed, Maulvi Azaharuddin & $\mathbf{M}$ & Backarganj West (M) \\
\hline Ahmed, Maulvi Emaduddin & $\mathbf{M}$ & Rajshahi South (M) \\
\hline Ahmed, $\mathrm{Mr} \mathrm{M}$. & $\mathbf{M}$ & Faridpur South (M) \\
\hline Ahmed, Maulvi Rafi Uddin & $\mathbf{M}$ & Jessore South (M) \\
\hline Ahmed, Munshi Jafar & $\mathbf{M}$ & Noakhali (M) \\
\hline Aley, Shaikh Mahboob & $\mathrm{M}$ & Not indicated \\
\hline Ali, Maulvi Syed Muksood & $\mathbf{M}$ & 24 Parganas North Municipal (M) \\
\hline Ali, Mr Syed Nasim & $\mathbf{M}$ & 24 Parganas Rural (M) \\
\hline Ali, Munshi Amir & $\mathbf{M}$ & Chittagong (M) \\
\hline Ali, Munshi Ayub & $\mathbf{M}$ & Chittagong (M) \\
\hline Arhamuddin, Maulvi Khandakar & $\mathbf{M}$ & Mymensingh West (M) \\
\hline $\begin{array}{l}\text { Azam, Khan Bahadur Khwaja } \\
\text { Mohamed }\end{array}$ & $\mathbf{M}$ & Dacca East Rural (M) \\
\hline Barma, Rai Sahib Panchanan & $\mathrm{H}$ & Rangpur (N-M) \\
\hline Birla, Babu Chaneshyamdas & $\mathrm{H}$ & Nominated Non-official - Marwari \\
\hline $\begin{array}{c}\text { Chaudhuri, Khan Bahadur } \\
\text { Maulvi Hafizar Rahman }\end{array}$ & $\mathbf{M}$ & Bogra (M) \\
\hline $\begin{array}{l}\text { Chaudhuri, Maulvi Shah } \\
\text { Muhammad }\end{array}$ & $\mathbf{M}$ & Malda cum Jalpalguri (M) \\
\hline Chaudhuri, Rai Harendranath & $\mathrm{H}$ & 24 Parganas Rural North (N-M) \\
\hline $\begin{array}{l}\text { Chaudhuri, the Hon'ble the } \\
\text { Nawab Saiyid Nawab Ali, } \\
\text { Khan Bahadur }\end{array}$ & $\mathbf{M}$ & Mymensingh East (M) \\
\hline Das, Babu Bhishmadev & $\mathrm{H}$ & $\begin{array}{l}\text { Nominated non-official depressed } \\
\text { classes }\end{array}$ \\
\hline Donald, Mr J. & C & Nominated official \\
\hline Doss, Rai Bahadur Pyari Lal & $\mathrm{H}$ & Dacca City (N-M) \\
\hline
\end{tabular}


TAble A-I (cont.)

\begin{tabular}{|c|c|c|}
\hline Name & Religion & Constituency \\
\hline French, Mr F. C. & C & Nominated official \\
\hline Ghatak, Rai Sahib Nilmani & $\mathbf{H}$ & Malda (N-M) \\
\hline $\begin{array}{l}\text { Ghose, Rai Bahadur Jegendra } \\
\text { Chunder }\end{array}$ & $\mathbf{H}$ & Calcutta University \\
\hline Hopkyns, Mr W. S. & C & Nominated official \\
\hline Karim, Maulvi Abdul & M & Faridpur North (M) \\
\hline Karim, Maulvi Fazlal & $\mathbf{M}$ & Backarganj South (M) \\
\hline Kerr, the Hon'ble Mr J. H. & C & $\begin{array}{l}\text { Nominated official Member Exec. } \\
\text { Council }\end{array}$ \\
\hline Khan, Babu Devendra Lal & $\mathbf{H}$ & Midnapore North (N-M) \\
\hline Khan, Maulvi Hamid-ud-din & $\mathbf{M}$ & Rangpur East (M) \\
\hline $\begin{array}{l}\text { Khan Chaudhuri, Khan Bahadur } \\
\text { Maulvi Muhammad Ershad Ali }\end{array}$ & M & Rajshahi North (M) \\
\hline $\begin{array}{l}\text { Maharajadhiraja Bahadur of } \\
\text { Burdwan, the Hon'ble }\end{array}$ & $\mathbf{H}$ & $\begin{array}{l}\text { Nominated official Member Exec. } \\
\text { Council }\end{array}$ \\
\hline Mukharji, Babu Satish Chandra & $\mathbf{H}$ & Hoogly cum Howrah Rural (N-M) \\
\hline $\begin{array}{l}\text { Mukhopadhaya, Babu Sarat } \\
\text { Chandra }\end{array}$ & $\mathrm{H}$ & Midnapore South (N-M) \\
\hline Mullick, Babu Nirode Bohary & $\mathrm{H}$ & Backarganj South (N-M) \\
\hline Nakey, Mirza Muhammad Ali & $\mathbf{M}$ & 24 Parganas Municipal South (M) \\
\hline O'Kinealy, Lt.-Col. Frederick* & C & Nominated official \\
\hline O'Malley, Mr L. S. S. & C & Nominated official \\
\hline $\begin{array}{l}\text { Pahlowan, Maulvi Md. Abdul } \\
\text { Jubbar }\end{array}$ & $\mathbf{M}$ & Mymensingh West (M) \\
\hline Poddar, Babu Keshoram & $\mathrm{H}$ & Bengal Marwari Association \\
\hline Rauf, Maulvi Shah Abdur & M & Rangpur West (M) \\
\hline Ray, Babu Surendra Nath & $\mathbf{H}$ & $\begin{array}{l}24 \text { Parganas Municipal South } \\
(\mathrm{N}-\mathrm{M})\end{array}$ \\
\hline Ray, Kumar Shib Shekhareswar & $\mathrm{H}$ & Rajshahi Landholders \\
\hline Roy, Mr Bijoy Prosad Singh & $\mathrm{H}$ & Burdwan (N-M) \\
\hline Roy, Babu Jogendra Krishna & $\mathrm{H}$ & Faridpur South (N-M) \\
\hline $\begin{array}{l}\text { Roy, Maharaja Bahadur } \\
\text { Kshaunish Chandra }\end{array}$ & $\mathrm{H}$ & Nadia (N-M) \\
\hline $\begin{array}{l}\text { Roy, Rai Bahadur Lalit Mohan } \\
\text { Singh }\end{array}$ & $\mathrm{H}$ & Burdwan Landholders \\
\hline Roy, Raja Maniloll Singh & $\mathbf{H}$ & Burdwan (N-M) \\
\hline Roy Chaudhuri, Babu Sailaja Nath & $\mathrm{H}$ & Khulna (N-M) \\
\hline Sarkar, Babu Rishindra Nath & $\mathrm{H}$ & Bankura West (N-M) \\
\hline Suhrawardy, Dr A. & M & Dacca West Rural (M) \\
\hline Suhrawardy, Dr Hassan & $\mathbf{M}$ & $\begin{array}{l}\text { Hoogly cum Howrah Municipal } \\
\text { (M) }\end{array}$ \\
\hline Suhrawardy, Mr Huseyn Shaheed & $\mathbf{M}$ & Burdwan South (M) \\
\hline
\end{tabular}

$\mathrm{H}=$ Hindu; $\mathbf{M}=$ Muslim; $\mathrm{C}=$ Christian; $(\mathrm{M})=$ Muslim constituency; $(\mathrm{N}-\mathrm{M})=$ Non-Muslim constituency.

23 Hindus, 27 Muslims and 6 Christians voted against.

Source: $B L C P$, vol. IV (Sept. 5, 1921), p. 476 . 
TABLE A-2

37 Legislators who Voted in Favor of Female Suffrage in Ig2I by Religion and Constituency

\begin{tabular}{|c|c|c|}
\hline Name & Religion & Constituency \\
\hline Ahmed, Maulvi Yakuinuddin & $\mathbf{M}$ & Dinajpur (M) \\
\hline Ali, Maulvi A. H. M. Wazir & $\mathrm{M}$ & Backarganj North (M) \\
\hline Ali, Mr Syed Erfan & $\mathrm{M}$ & Nadia (M) \\
\hline Banerjea, the Hon'ble Sir Surendra Nath & $\mathrm{H}$ & 24 Parganas Municipal (N-M) \\
\hline Banerjea, Rai Bahadur Abinash Chandra & $\mathrm{H}$ & Birbhum (N-M) \\
\hline Barton, $\mathrm{Mr} \mathrm{H}$. & $\mathrm{C}$ & Anglo-Indian \\
\hline Basu, Babu Jatindra Nath & $\mathrm{H}$ & Calcutta North (N-M) \\
\hline Bose, Mr S. M. & $\mathrm{H}$ & Mymensingh East (N-M) \\
\hline Charmakar, Babu Rasik Chandra & $\mathrm{H}$ & Noakhali (N-M) \\
\hline Das, Mr S. R. & $\mathrm{H}$ & Calcutta North West (N-M) \\
\hline Das Cupta, Babu Nibaran Chandra & $\mathrm{H}$ & Backarganj North (N-M) \\
\hline De, Babu Fanindralal & $\mathrm{H}$ & $\begin{array}{l}\text { Hoogly cum Howrah Rural } \\
(\mathrm{N}-\mathrm{M})\end{array}$ \\
\hline Dutt, Mr Ajoy Chunder & $\mathbf{H}$ & Bankura East (N-M) \\
\hline Dutta, Babu Indu Bhushan & $\mathrm{H}$ & Tippera (N-M) \\
\hline Faroqui, K. C. M. & $\mathbf{M}$ & Tippera (M) \\
\hline Ghose, Mr D. C. & $\mathrm{H}$ & 24 Parganas Rural South \\
\hline Gordon, Mr A. D. & $\mathrm{C}$ & Indian Tea Association \\
\hline Haq, Maulvi A. K. Fazl-ul & $\mathbf{M}$ & Khulna (M) \\
\hline Khan, Maulvi Md. Rafique Uddin & $\mathrm{M}$ & Mymensingh East (M) \\
\hline Khan, Mr Razaur Rahman & $\mathrm{M}$ & Calcutta North (M) \\
\hline Lang, Mr J. & C & Nominated official \\
\hline Larmour, Mr F. A. & $\mathrm{C}$ & Calcutta Trades Association \\
\hline Makramali, Munshi & $\mathrm{M}$ & Noakhali (M) \\
\hline McKenzie, Mr D. P. & $\mathrm{C}$ & Indian Jute Mills Association \\
\hline Mitter, the Hon'ble Mr P. C. & $\mathrm{H}$ & Presidency Landholders \\
\hline Moitra, Dr Jatindra Nath & $\mathrm{H}$ & Faridpur North $(\mathrm{N}-\mathrm{M})$ \\
\hline Mukherji, Professor S. C. & $\mathrm{C}$ & $\begin{array}{l}\text { Nominated Non-official Indian } \\
\text { Christian }\end{array}$ \\
\hline Mullick, Babu Surendra Nath & $\mathrm{H}$ & Calcutta South (N-M) \\
\hline Raikat, Mr Prasanna Deb & $\mathrm{H}$ & Jalpaiguri (N-M) \\
\hline Ray, Babu Bhabendra Chandra & $\mathrm{H}$ & Jessore North (N-M) \\
\hline Ray, Rai Bahadur Upendra Lal & $\mathrm{H}$ & Chittagong Landholders \\
\hline Ray Chaudhuri, Mr Krishna Chandra & $\mathrm{H}$ & Nominated Non-official Labor \\
\hline Ray Choudhury, Raja Manmatha Nath & $\mathrm{H}$ & Mymensingh West $(\mathrm{N}-\mathrm{M})$ \\
\hline Roy, Babu Jogendra Nath & $\mathrm{H}$ & Dacca Rural (N-M) \\
\hline Roy, Babu Nalini Nath & $\mathrm{H}$ & Jessore South (N-M) \\
\hline Roy, Mr J. E. & $\mathrm{C}$ & Bengal Chamber of Commerce \\
\hline Stark, Mr H. A. & $\mathrm{C}$ & Anglo-Indian \\
\hline
\end{tabular}

$\mathbf{M}=$ Muslim; $\mathbf{H}=$ Hindu; $\mathbf{C}=$ Christian; $(\mathrm{M})=$ Muslim electorate $(\mathrm{N}-\mathrm{M})=$ Non-Muslim electorate.

2) Hindus, 8 Muslims and 8 Christians voted in favor.

Source: $B L C P$, vol. IV (Sept. 5,1921 ), p. 476 . 


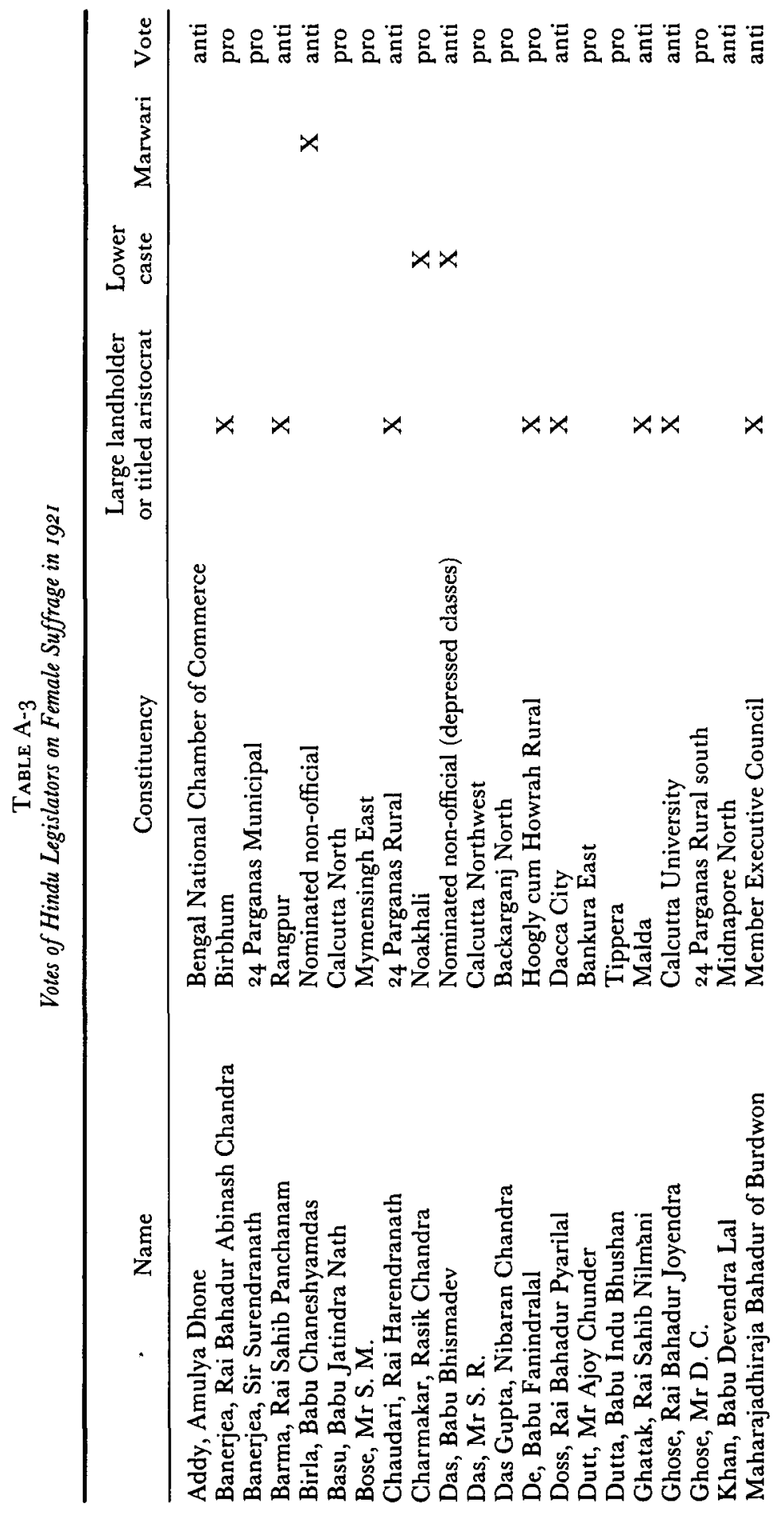



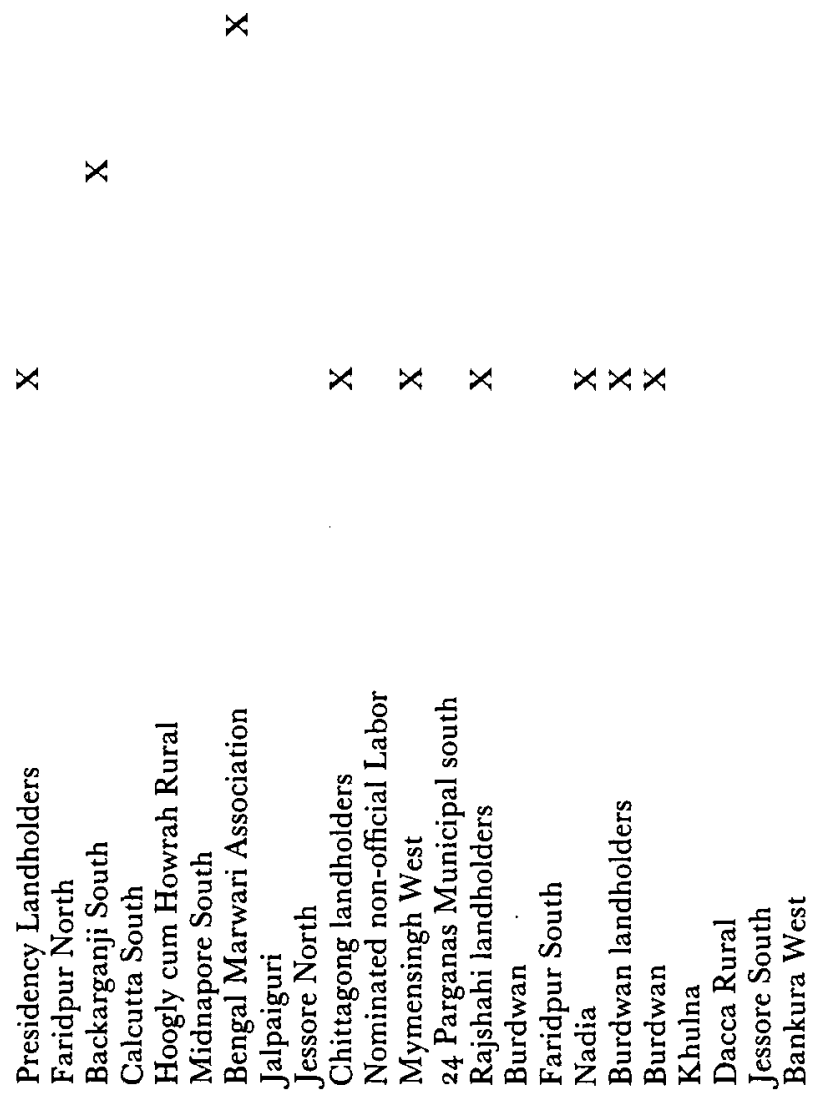

递

응

उับ

帘

蛋

$\times \quad \times \times \times x \times x$

o

$\stackrel{2}{2}$

起

용

ही

$\bar{\square}$

응

응

웅

उั

o 3

की

s.

类

을

亘品

흐웜

过

움음

空

品

ㅇำ

돈

ปे

Еू

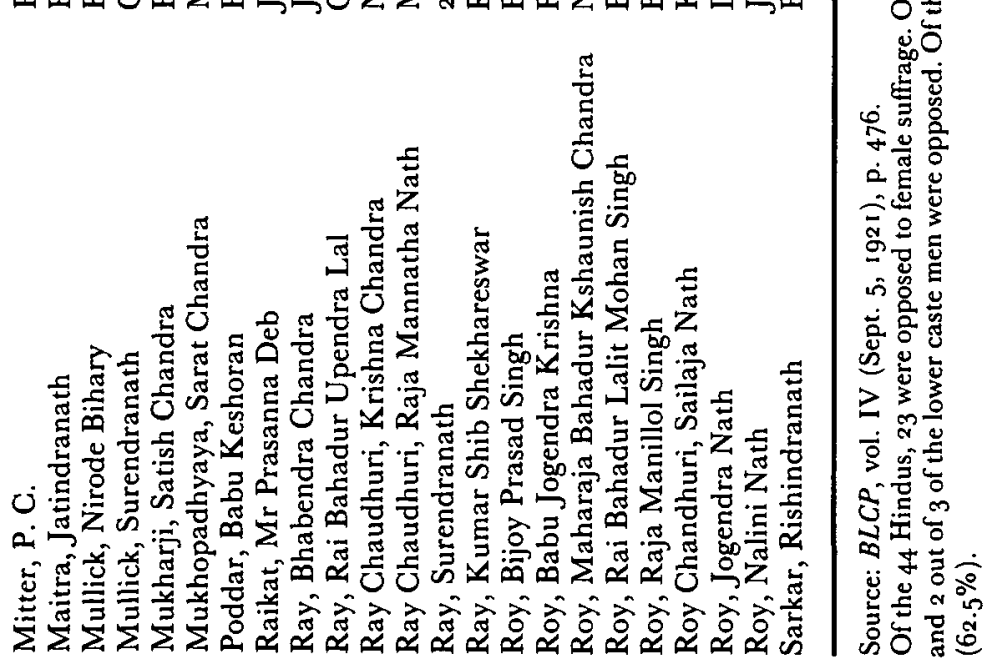


TABLE A-4

Votes of British Legislators on Female Suffrage in 192I

\begin{tabular}{llc}
\hline Name & \multicolumn{1}{c}{ Constituency } & Vote \\
\hline Donald, Mr J. & Nominated official & anti \\
French, Mr F. C. & Nominated official & anti \\
Gordon, Mr A. P. & Elected-Indian Tea Association & pro \\
Hopkyns, Mr W. S. & Nominated official & anti \\
Kerr, Mr J. H. & Nominated official (Member Exec. Council) & anti \\
Lang, Mr J. & Nominated official & pro \\
Larmour, Mr E. A. & Elected-Calcutta Trades Association & pro \\
McKenzie, D. P. & Elected-Indian Jute Mills Association & pro \\
O'Kineally, Lt.-Col. Frederick & Nominated official & anti \\
O'Malley, L. S. S. & Nominated official & anti \\
Roy, Mr J. E. & Elected-Bengal Chamber of Commerce & pro \\
\hline
\end{tabular}

Source: $B L C P$, vol. IV (Sept. 5, 1921), p. 476 .

Of the I I British legislators 6 voted against and 5 voted in favor.

Among the nominated officials 6 out of 7 voted against.

All elected British legislators voted in favor.

TABLE B-I

Legislators Voting for and Against Female Suffrage, 1925

Ayes

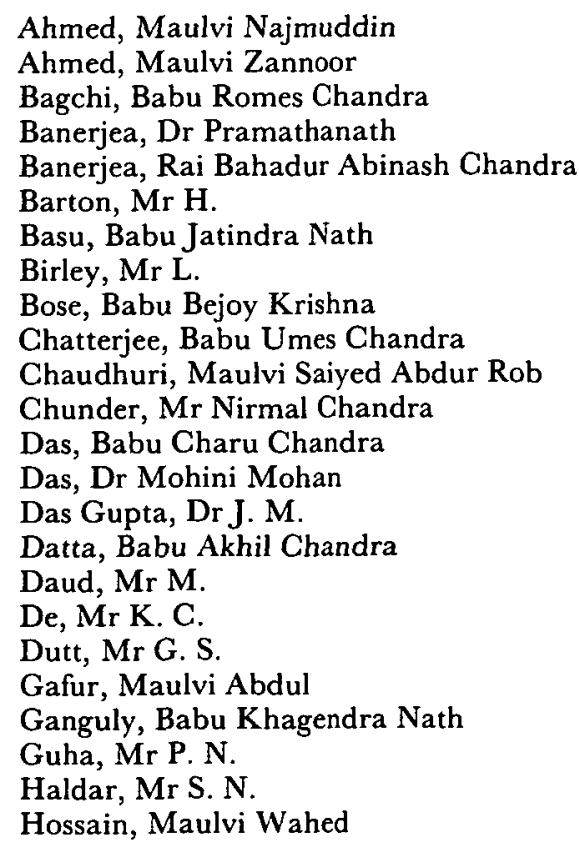


TABLE B-1 (cont.)

\section{Ayes}

Huq, Maulvi Ekramul

James, Mr F. E.

Joardar, Maulvi Aftab Hossain

Khaitan, Babu Debi Prosad

Khan, Babu Debendra Lal

Khan, Maulvi Abdur Raschid

Khan, Maulvi Mahi Uddin

Liddell, Mr H. C.

Mitra, Babu Jogendra Nath

Mitter, Sir Provash Chunder

Moreno, Dr H. W. B.

Mukerjea, Babu Taraknath

Nasker, Babu Hem Chandra

Neogi, Babu Manmohon

Quader, Maulvi Abdul

Raikat, Mr Prasanna Deb

Ray, Babu Abanish Chandra

Ray, Dr Kumud Sankar

Ray Chaudhuri, Mr K. C.

Ray Chaudhuri, Raja Manmatha Nath of Santosh

Roy, Dr Bidhan Chandra

Roy, Mr Kiran Sankar

Salam, Khan Bahadur Maulvi Abdus

Sarkar, Babu Hemanta Kumar

Sarker, Babu Naliniranjan

Sen, Mr N. C.

Sen Gupta, Mr J. M.

Suhrawardy, Dr A.

Wilson, Lt-Col. R. P.

Woodhead, Mr J. A.

Addams-Williams, Mr C.

Noes

Addy, Babu Amulya Dhone

Ahamad, Maulvi Asimuddin

Ahmed, Maulvi Tayebuddin

Ali, Maulvi Sayyed Sultan

Banerjee, Mr A. C.

Barma, Rai Sahib Panchanan

Chakravorty, Babu Sudarsan

Chaudhuri, Rai Harendranath

Chaudhuri, Nawab Bahadur Saiyid Nawab Ali, Khan Bahadur

Chaudhury, Maulvi Md. Nurul Huq

Chowdhury, Maulvi Fazlal Karim

Dey, Babu Boroda Prosad

Doss, Rai Bahadur Pyari Lal

Forrester, Mr J. Campbell

Ghuznavi Hadji Mr A. K. Abu Ahmed Khan

Haq, Khan Bahadur Kazi Zahirul

Haq, Shah Syed Emdadul 
Hoque, Maulvi Sayedul

Hossain, Khan Bahadur Maulvi Musharruf

Lal Mohammed, Haji

Lindsay, $\mathrm{Mr}$ J. H.

Maity, Babu Mahendra Nath

Masih, Mr Syed M.

Nazimuddin, Khaje

Oaten, Mr E. F.

Pahlowan, Maulvi Md. Abdul Jubbar

Rahim, The Hon'ble Sir Abd-Ur

Rahman, Mr A. F.

Ray, Babu Nagendra Narayan

Ray, Babu Surendra Nath

Ray, The Hon'ble Maharaja Kshaunish Chandra, Bahadur of Nadia

Roy, Mr D. N.

Roy, Raja Maniloll Singh

Sarkar, Maulvi Allay Bukhsh

Stephenson, The Hon'ble Sir Hugh

Suhrawardy, Mr H. S.

Tarafdar, Maulvi Rajib Uddin

Source: BLCP, vol. XVIII (Aug. 19, 1925), p. 307

TABLE B-2

Votes of Legislators who were Present for Both the 1921 and 1925 Vote on Female Suffrage in the Bengal Legislative Council

\begin{tabular}{lcc}
\hline \multicolumn{1}{c}{ Name } & I921 Vote & I925 Vote \\
\hline Rai Bahadur Abinash Chandra Banerjee & pro & pro \\
Mr H. Barton & pro & pro \\
Babu Jatindranath Basu & pro & pro \\
Babu Amulya Dhone Addy & anti & anti \\
Rai Sahib Panchanan Barma & anti & anti \\
Rai Harendranath Chaudhuri & anti & anti \\
Nawab Bahadur Saiyid Nawab Ali, Khan Bahadur & anti & anti \\
Rai Bahadur Pyari Lal Doss & anti & anti \\
Mr Prasanna Deb Raikat & pro & pro \\
Mr K. C. Ray Chaudhuri & pro & pro \\
Raj Manmatha Nath Ray Chaudhuri & pro & pro \\
Maulvi Md. Abdul Jubbar Pahlowan & anti & anti \\
Surendranath Ray & anti & anti \\
Maharaja Kshaunish Chandra, Bahadur of Nadia & anti & anti \\
Raja Maniloll Singh Roy & anti & anti \\
Dr A. Suhrawardy & anti & pro \\
Mr H. S. Suhrawardy & anti & anti \\
\hline
\end{tabular}

Source: $B L C P$, vol. IV (Sept. 5, 1921), p. 416; BLCP, vol. XVIII (Aug. 19, 1925), p. 307. 
TABLE B-3

Votes of British Legislators on Female Suffrage in 1925

\begin{tabular}{lll}
\hline \multicolumn{1}{c}{ Name } & \multicolumn{1}{c}{ Constituency } & Vote \\
\hline Mr C. Addams Williams & Nominated official & anti \\
Mr L. Birley & Nominated official & pro \\
Mr J. Campbell Forrester & Elected representative Presidency and Europeans & pro* \\
Mr F. E. James & Elected representative Presidency and Europeans & pro \\
Mr H. C. Liddell & Nominated official & pro \\
Mr.J. S. Lindsay & Nominated official & anti \\
Mr E. F. Oaten & Nominated official & anti \\
Lt-Colonel R. B. Wilson & Nominated official & pro \\
Mr J. A. Woodhead & Nominated official & pro \\
Mr Hugh Stephensen & Nominated official Member Executive Council & anti \\
& & \\
\hline
\end{tabular}

* Mr J. Campbell Forrester actually voted against, but his vote has been counted as pro because he made a strong speech in favor of female suffrage and publicly apologized for mistakenly going the wrong way when a vote division was taken.

Source: BLCP, vol. XVIII (Aug. 19, 1925), p. 307; vol. XVII (Aug. 1925), Alphabetical List of Members, pp. vii-xi.

Six British legislators voted in favor and four against.

The two elected members voted in favor, but 4 out of 8 nominated members voted against.

TABLE B-4

Votes of Swarajist and Non-Swarajist Muslim Legislators on Female Suffrage in 1925

\begin{tabular}{llc}
\hline \multicolumn{1}{c}{ Name } & \multicolumn{1}{c}{$\begin{array}{c}\text { Political } \\
\text { orientation }\end{array}$} & $\begin{array}{c}\text { Vote on } \\
\text { female suffrage }\end{array}$ \\
\hline Maulvi Asimaddin Ahamed & Swarajist & anti \\
Maulvi Tayebuddin Ahmed & Non-Swarajist & anti \\
Maulvi Najmuddin Ahmed & Swarajist & pro \\
Maulvi Zannoor Ahmed & Non-Swarajist & pro \\
Maulvi Sayyed Sultan & Non-Swarajist & anti \\
Maulvi Saiyid Abdur Rob Chaudhuri & Swarajist & pro \\
Nawab Bahadur Saiyid Nawab Ali Chaudhuri & Non-Swarajist & anti \\
Khan Bahadur* & & \\
Maulvi Md. Nurul Huq Chaudhury & Swarajist & anti \\
Maulvi Fazlal Karim Choudhury & Non-Swarajist & anti \\
Mr M. Daud & Non-Swarajist & pro \\
Maulvi Abdul Gafur & Swarajist & pro \\
Hadji A. K. Abu Ahmed Khan Ghuznavi & Non-Swarajist & anti \\
Maulvi Sayedul Hoque & Swarajist & anti \\
Khan Bahadur Maulvi Musharruf Hossain* & Non-Swarajist & anti \\
Maulvi Wahed Hossein & Swarajist & pro \\
Maulvi Ekramul Huq & Non-Swarajist & pro \\
Khan Bahadur Kazi Zahirul Haq* & Non-Swarajist & anti \\
Shah Syed Emdadul Huq & Non-Swarajist & anti \\
Maulvi Aftab Hossain Joardar & Swarajist & pro \\
Maulvi Abdur Raschid Khan & Swarajist & pro \\
Maulvi Mahi Uddin Khun & Swarajist & pro
\end{tabular}


TABLE B-4 (cont.)

Votes of Swarajist and Non-Swarajist Muslim Legislators on Female Suffrage in 1925

\begin{tabular}{llc}
\hline \multicolumn{1}{c}{ Name } & \multicolumn{1}{c}{$\begin{array}{c}\text { Political } \\
\text { orientation }\end{array}$} & $\begin{array}{c}\text { Vote on } \\
\text { female suffrage }\end{array}$ \\
\hline $\begin{array}{l}\text { Hadji Lal Muhammed } \\
\text { Mr Syed M. Masih }\end{array}$ & Non-Swarajist & anti \\
Khaje Nazimuddin & Non-Swarajist & anti \\
Maulvi Abdul Jubbar Pahlowan & Non-Swarajist & anti \\
Maulvi Abdul Quader & Non-Swarajist & anti \\
Hon. Sir Abdur Rahim & Non-Swarajist & pro \\
Mr A. F. Rahman & Non-Swarajist & anti \\
Khan Bahadur Maulvi Abdas Salam* & Non-Swarajist & anti \\
Maulvi Allah Bukhsh Sarkar & Non-Swarajist & pro \\
Dr A. Suhrawardy & Non-Swarajist & anti \\
Mr H. S. Suhrawardy & Swarajist & pro \\
Maulvi Rajib Uddin Tarafdar & Non-Swarajist & anti \\
\hline
\end{tabular}

*Titled aristocrats.

Source: BLCP, vol. XVIII (Aug. 19, 1925), p. 307.

TABLE B-5

Votes of Swarajist and Non-Swarajist Hindu Legislators on Female Suffrage in 1925

\begin{tabular}{lll}
\hline \multicolumn{1}{c}{ Name } & \multicolumn{1}{c}{$\begin{array}{c}\text { Political } \\
\text { orientation }\end{array}$} & Vote \\
\hline Babu Romes Chandra Bagchi & \multicolumn{1}{c}{ Swarajist } & pro \\
Amulya Dhone Addy & Non-Swarajist & anti \\
Mr A. C. Banerjee & Swarajist & anti \\
Dr Pramanath Banerjea & Non-Swarajist & pro \\
Rai Bahadur Abinash Chandra Banerjea* & Non-Swarajist & pro \\
Rai Sahib Panchanan Barma* & Non-Swarajist & anti \\
Babu Jatindranath Basu & Non-Swarajist & pro \\
Babu Bejoy Krishna Bose & Swarajist & pro \\
Babu Sudarsan Chakravarty & Non-Swarajist & anti \\
Babu Umesh Chandra Chatterjee & Swarajist & pro \\
Nirmal Chandra Chunder & Swarajist & pro \\
Dr Mohini Mohan Das $\dagger$ & Swarajist & pro \\
Rai Harendranath Chaudhuri* & Non-Swarajist & anti \\
Babu Charu Chandra Das $\dagger$ & Non-Swarajist & pro \\
J. M. Dasgupta & Swarajist & pro \\
Akhil Chandra Datta & Non-Swarajist & pro \\
Babu Baroda Prasad Dey & Swarajist & anti \\
Rai Bahadur Pyari Lal Doss* & Non-Swarajist & anti \\
Mr K. C. Dey & Non-Swarajist & pro \\
Mr G. S. Dutt & Non-Swarajist & pro \\
Babu Khagendranath Ganguly & Swarajist & pro \\
Mr P. N. Guhu & Non-Swarajist & pro \\
& &
\end{tabular}


TABLE B-5 (cont.)

Votes of Swarajist and Non-Swarajist Hindu Legislators on Female Suffrage in 1925

\begin{tabular}{lll}
\hline \multicolumn{1}{c}{ Name } & \multicolumn{1}{c}{$\begin{array}{c}\text { Political } \\
\text { orientation }\end{array}$} & Vote \\
\hline Mr S. N. Haldar & Non-Swarajist & pro \\
Babu Debendra Lal Khan & Non-Swarajist & pro \\
Babu Debi Prosad Khaitan & Non-Swarajist & pro \\
Mr P. C. Mitter* & Non-Swarajist & pro \\
Babu Makendranath Maity & Swarajist & anti \\
Babu Jogendranath Mitra & Swarajist & pro \\
Babu Tarahnath Mukherjea & Non-Swarajist & pro \\
Babu Hem Chandra Nasker & Swarajist & pro \\
Babu Manmohan Neogi & Swarajist & pro \\
Prosanna Deb Raikat & Swarajist & pro \\
Babu Abinash Chandra Ray & Swarajist & pro \\
Nagendra Narayan Ray & Non-Swarajist & anti \\
Babu Surendranath Ray & Non-Swarajist & anti \\
Mr D. N. Roy & Swarajist & anti \\
Raja Maniloll Singh Roy* & Non-Swarajist & anti \\
J. M. Sen Gupta & Swarajist & pro \\
Mr N. C. Sen & Non-Swarajist & pro \\
Nalini Ranjan Sarkar & Swarajist & pro \\
Hemanta Kumar Sarkar $\dagger$ & Swarajist & pro \\
Mr Kiron Sankar Roy & Swarajist & pro \\
Dr B. C. Roy & Non-Swarajist & pro \\
Mr K. C. Ray Chaudhury $\dagger$ & Non-Swarajist & pro \\
Dr Kumud Sarkar Ray & Swarajist & pro \\
Hon'ble Maharaja Ksaunish Chunder Ray* & Non-Swarajist & anti \\
Raja Manmatha Nath Roy Chaudhuri of Santosh* & Non-Swarajist & pro \\
\hline & & \\
\hline
\end{tabular}

*Aristocrats and large landholders.

†Spokesmen for lower classes.

Dr Mohini Mohan Das and Babu Chau Chandra Das spoke for backward castes. Mr K. C. Ray Chaudhury spoke for laboring classes and Hemanta Kumar Sarkar spoke for tenant interests.

Source: BLCP, XVIII (Aug. 19, 1925), p. 307. 